\title{
SIRPa-aCD123 fusion antibodies targeting CD123 in conjunction with CD47 blockade enhance the clearance of AML-initiating cells
}

Siret Tahk' ${ }^{1}$, Binje Vick ${ }^{2,3}$, Björn Hiller ${ }^{1}$, Saskia Schmitt ${ }^{1}$, Anetta Marcinek ${ }^{4,5}$, Enrico D. Perini ${ }^{1}$, Alexandra Leutbecher ${ }^{4,5}$, Christian Augsberger ${ }^{4,5}$, Anna Reischer ${ }^{4,5}$, Benjamin Tast ${ }^{4,5}$, Andreas Humpe ${ }^{6}$, Irmela Jeremias ${ }^{2,3,7}$, Marion Subklewe ${ }^{3,4,5}$, Nadja C. Fenn ${ }^{1 *}$ and Karl-Peter Hopfner ${ }^{1 *}$ (1)

\begin{abstract}
Background: Acute myeloid leukaemia (AML) stem cells (LSCs) cause disease relapse. The CD47 "don't eat me signal" is upregulated on LSCs and contributes to immune evasion by inhibiting phagocytosis through interacting with myeloid-specific signal regulatory protein alpha (SIRPa). Activation of macrophages by blocking CD47 has been successful, but the ubiquitous expression of CD47 on healthy cells poses potential limitations for such therapies. In contrast, CD123 is a well-known LSC-specific surface marker utilized as a therapeutic target. Here, we report the development of SIRPa-aCD123 fusion antibodies that localize the disruption of CD47/SIRPa signalling to AML while specifically enhancing LSC clearance.
\end{abstract}

Methods: SIRPa-aCD123 antibodies were generated by fusing the extracellular domain of SIRPa to an aCD123 antibody. The binding properties of the antibodies were analysed by flow cytometry and surface plasmon resonance. The functional characteristics of the fusion antibodies were determined by antibody-dependent cellular phagocytosis and antibody-dependent cellular cytotoxicity assays using primary AML patient cells. Finally, an in vivo engraftment assay was utilized to assess LSC targeting.

Results: SIRPa-aCD123 fusion antibodies exhibited increased binding and preferential targeting of CD $123^{+} \mathrm{CD}_{4} 7^{+}$ AML cells even in the presence of CD47 ${ }^{+}$healthy cells. Furthermore, SIRPa-aCD123 fusion antibodies confined disruption of the CD47-SIRPa axis locally to AML cells. In vitro experiments demonstrated that SIRPa-aCD123 antibodies greatly enhanced AML cell phagocytosis mediated by allogeneic and autologous macrophages. Moreover, SIRPaaCD123 fusion antibodies efficiently targeted LSCs with in vivo engraftment potential.

Conclusions: SIRPa-aCD123 antibodies combine local CD47 blockade with specific LSC targeting in a single molecule, minimize the risk of targeting healthy cells and efficiently eliminate AML LSCs. These results validate SIRPaaCD123 antibodies as promising therapeutic interventions for AML.

Keywords: CD47, Acute myeloid leukaemia, CD123, Leukemic stem cells, Phagocytosis, Immunotherapy

*Correspondence: nfenn@genzentrum.Imu.de; hopfner@genzentrum.Imu.de ${ }^{1}$ Gene Center and Department of Biochemistry, Ludwig-MaximiliansUniversität München, Feodor-Lynen-Straße 25, 81377 Munich, Germany Full list of author information is available at the end of the article

\section{Background}

Therapeutic options for acute myeloid leukaemia (AML) are limited, and the majority of patients relapse due to persistent chemorefractory LSCs [1-3]. Targeting and eradicating the leukemic stem cell (LSC) population is therefore a prerequisite for sustained original author(s) and the source, provide a link to the Creative Commons licence, and indicate if changes were made. The images or other third party material in this article are included in the article's Creative Commons licence, unless indicated otherwise in a credit line to the material. If material is not included in the article's Creative Commons licence and your intended use is not permitted by statutory regulation or exceeds the permitted use, you will need to obtain permission directly from the copyright holder. To view a copy of this licence, visit http://creativecommons.org/licenses/by/4.0/. The Creative Commons Public Domain Dedication waiver (http://creativeco mmons.org/publicdomain/zero/1.0/) applies to the data made available in this article, unless otherwise stated in a credit line to the data. 
remission. $\mathrm{CD} 47$ is an innate immune checkpoint upregulated on LSCs, where it functions as a "don't eat me" signal by interacting with SIRP $\alpha$ on myeloid cells [4-6]. The first in class CD47-blocking antibody, magrolimab (Hu5F9-G4), was evaluated as a monotherapy in AML in a phase 1 trial (NCT02678338) [7, 8]. However, preclinical data support the combination of magrolimab with pro-phagocytic signals, such as activation of $\mathrm{Fc} \gamma$ receptors $(\mathrm{Fc} \gamma \mathrm{R})$ on macrophages or expression of calreticulin on target cells [8-12]. Magrolimab has consequently been combined with calreticulin-inducing azacytidine in a phase $1 \mathrm{~b}$ trial including untreated AML patients unfit for chemotherapy and patients with intermediate to very highrisk myelodysplastic syndrome (MDS) $[8,13]$. The combination demonstrated encouraging results; $64 \%$ of AML patients achieved an objective response (OR), while 56\% achieved complete remission (CR) or CR with incomplete haematological recovery. In patients with high-risk MDS, $91 \%$ had an OR, and $42 \%$ had a CR (NCT03248479).

Nevertheless, CD47 is ubiquitously expressed on healthy cells as well, which generates an antigen sink lowering the effective dose and comprising a potential site of toxicity for $\alpha \mathrm{CD} 47$ therapies $[14,15]$. Combining the CD47 blocking domain, such as endogenous SIRP $\alpha$, with a cancer-specific antibody in a single molecule can restrict the blockade of CD47 locally on antigenexpressing cells [16-18].

Similar to CD47, the interleukin-3 receptor alpha chain (CD123) is upregulated on AML LSCs and is associated with increased proliferation of AML cells and a poor prognosis [19-21]. Furthermore, high CD47 and CD123 coexpression has been demonstrated to correlate with AML chemoresistance [22]. These studies suggest that dual targeting of CD123 and CD47 could reduce the LSC count and enhance the rate and duration of response in AML patients.

To improve AML LSC targeting and clearance, we fused an $\alpha C D 123$ antibody with the endogenous N-terminal SIRP $\alpha$ immunoglobulin V-like domains and generated $1 \times$ SIRP $\alpha-\alpha C D 123$ and $2 \times \operatorname{SIRP} \alpha-\alpha C D 123$ fusion antibodies. Both of our antibodies exhibited improved binding to $\mathrm{CD} 123^{+} \mathrm{CD} 47^{+}$cells and stimulated efficient natural killer (NK) cell-mediated lysis of AML compared to the conventional $\alpha C D 123$ antibody in vitro. Importantly, SIRP $\alpha-\alpha C D 123$ fusion antibodies blocked CD47 locally on CD123 ${ }^{+}$cells and induced phagocytosis of primary AML cells by allogeneic and autologous macrophages in vitro. Finally, the $2 \times \operatorname{SIRP} \alpha-\alpha C D 123$ antibody targeted LSCs that are capable of engrafting and reinitiating $\mathrm{AML}$ in an in vivo model.

\section{Materials and methods}

\section{Expression and purification of the antibodies}

$\alpha C D 123$ antibody light and heavy chain plasmids were generated by cloning the $\alpha \mathrm{CD} 123$ variable light $\left(\mathrm{V}_{\mathrm{L}}\right)$ and variable heavy $\left(\mathrm{V}_{\mathrm{H}}\right)$ sequences of talacotuzumab [23] into the respective pFUSE2-CLIg-hK and pFUSECHIg-hG1 vectors (InvivoGen). For $1 \times \operatorname{SIRP} \alpha-\alpha \mathrm{CD} 123$ and $2 \times \operatorname{SIRP} \alpha-\alpha \mathrm{CD} 123$, one or two N-terminal SIRP $\alpha$ variant 1 immunoglobulin V-like domains (amino acids 31-149) were subcloned from a previously described construct [18] into the $\mathrm{N}$-terminus of the $\alpha \mathrm{CD} 123 \mathrm{~V}_{\mathrm{L}}$ using a $\left(\mathrm{Gly}_{4} \mathrm{Ser}\right)_{4}$ linker. The $\alpha \mathrm{CD} 19 \mathrm{~V}_{\mathrm{L}}$ and $\mathrm{V}_{\mathrm{H}}$ plasmids (clone 4G7) were cloned to generate the control molecules. The $\alpha C D 47$ (clone Hu5F9) $V_{L}$ and $V_{H}$ sequences [24] were subcloned into pFUSE2-CLIg-hK and pFUSE-CHIg-hG4, respectively. The SIRP $\alpha-F c$ fusion construct (similar to TTI-621) [25] was generated by fusing the N-terminal $\mathrm{V}$ domain of human SIRP $\alpha$ variant 2 [26] to the human IgG1 Fc region of a pFUSE-CHIg-hG1 vector (InvivoGen). The plasmids were transfected into Expi293F cells (Thermo Fisher Scientific) according to the manufacturer's protocol. After five to seven days, the supernatant was harvested, and antibodies were purified by protein $\mathrm{A}$ affinity chromatography followed by size exclusion chromatography using a Superdex 200 increase 10/300 GL column (GE Healthcare). Antibodies were analysed by sodium dodecyl sulphate (SDS) polyacrylamide gel electrophoresis, and stability was measured using a Tycho NT.6 (NanoTemper Technologies). The coding sequence for the CD123 extracellular domain was amplified by PCR from complementary DNA of L-428 cells and subcloned into pSecTag2/HygroC containing a His $_{6}$-tag (Thermo Fisher Scientific). CD123 was expressed in Expi293F cells and purified by nickel affinity chromatography and size exclusion chromatography.

\section{Surface plasmon resonance analysis}

Binding of the $\alpha \mathrm{CD} 123$ antibodies to CD123 was measured using a Biacore X100 (Biacore). Antibodies were captured on a CM5 sensor chip using the Human Antibody Capture Kit (both GE Healthcare). CD123 was used at concentrations of 3.91-1000 $\mathrm{nM}$, and equilibrium dissociation constants $\left(K_{\mathrm{D}}\right)$ were calculated from the ratio of the rate constants $\left(k_{o f f} / k_{o n}\right)$ of the multicycle kinetics measurements using Biacore Evaluation software.

\section{Cell lines}

All cell lines were cultured under standard conditions. MOLM-13 and Raji cells were purchased from the Deutsche Sammlung von Mikroorganismen und Zellkulturen (DSMZ). Chinese hamster ovary ( $\mathrm{CHO}$ ) cells stably overexpressing human CD47 were previously generated [18]. Expi293F cells were obtained from Thermo Fisher 
Scientific. Cell lines were routinely screened for mycoplasma contamination.

\section{Patient and healthy donor material}

At initial diagnosis or relapse, AML patient samples were characterized at the Laboratory for Leukemia Diagnostics of the Klinikum der Universität München as previously described [27-29]. Peripheral blood mononuclear cells (PBMCs) were isolated from healthy donor (HD) blood or residual cells of leukoreduction chambers by Biocoll (Biochrom). RBCs were collected from HD peripheral blood. Platelet-rich plasma (PRP) was isolated from HD peripheral blood by centrifugation at $200 \times g$ for $20 \mathrm{~min}$ at $25{ }^{\circ} \mathrm{C}$. In the binding studies, platelets were isolated from PRP in the presence of prostaglandin E1 (Merck). For patient-derived xenograft (PDX) cells, AML patient cells were serially transplanted into NOD/ SCID gamma null mice (NOD.Cg-Prkdc ${ }^{\text {scid }}$ IL2 g $^{\text {tm1Wjl } /}$ SzJ, NSG). PDX cells were transduced with luciferase and mCherry lentiviral constructs for bioluminescence imaging [23]. For ex vivo experiments, PDX cells were grown in StemPro-34 medium with 2\% FBS, L-glutamine and penicillin-streptomycin (all Gibco) supplemented with rhIL3, rhTPO, rhSCF (all Peprotech) and rhFLT3-ligand (R\&D Systems). Patient characteristics are summarized in Table 1 and Additional file 1: Table S1.

\section{Antibodies and flow cytometry}

Commercial antibodies were from Biolegend (San Diego) unless otherwise stated. Human IgG1 isotype control (QA16A12) and $\alpha \mathrm{CD} 47$ (B6H12, eBioscience) were used in binding, CD47 blocking and functional experiments. FITC or APC $\alpha$ human IgG ( $\alpha$ hIgG, HP6017) was used for binding, and FITC $\alpha \mathrm{CD} 47$ (B6H12, eBioscience) was used in $\mathrm{CD} 47$ blocking experiments for secondary staining. APC and FITC isotype (MOPC-21), APC $\alpha \mathrm{CD} 123$ (6H6) and FITC $\alpha \mathrm{CD} 47$ (B6H12) were used for surface expression analysis. Surface antigen density was evaluated using QIFIKIT (Agilent Technologies). Flow cytometry was performed using the Guava easyCyte 6HT (Merck Millipore), the Cytoflex LX (Beckman Coulter) or the BD LSRFortessa (Becton Dickinson). As a measure

Table 1 Patient characteristics

\begin{tabular}{|c|c|c|c|c|c|c|c|}
\hline Patient & Age & Sex & $\begin{array}{l}\text { Disease } \\
\text { status }\end{array}$ & Karyotype & ELN genetic group & FLT3-ITD & NPM1 \\
\hline 0276 & 29 & $\mathrm{~F}$ & $\mathrm{ID}$ & Aberrant & Adverse & wt & wt \\
\hline 2562 & 52 & $M$ & $\mathrm{ID}$ & Intermediate aberrant & n.a. & wt & wt \\
\hline 3140 & 74 & $M$ & $\mathrm{ID}$ & Normal & Intermediate & wt & wt \\
\hline 3073 & 54 & M & $\mathrm{R}$ & Normal & Favourable & wt & wt \\
\hline 1233 & 49 & $\mathrm{~F}$ & $\mathrm{ID}$ & Complex aberrant & Adverse & mut & mut \\
\hline 3826 & 85 & M & $\mathrm{ID}$ & Aberrant & Adverse & wt & wt \\
\hline 2449 & 30 & $F$ & ID & Aberrant & Favourable & wt & wt \\
\hline 4169 & 20 & $M$ & $\mathrm{ID}$ & Aberrant & Intermediate & wt & wt \\
\hline 0178 & 56 & $\mathrm{~F}$ & $\mathrm{ID}$ & Complex aberrant & Favourable & wt & wt \\
\hline 3386 & 52 & $M$ & $\mathrm{ID}$ & Normal & Favourable & wt & mut \\
\hline 3776 & 35 & $\mathrm{~F}$ & $\mathrm{ID}$ & Normal & Favourable & wt & wt \\
\hline 3221 & 59 & M & $\mathrm{ID}$ & Normal & Favourable & wt & mut \\
\hline 3495 & 58 & $M$ & $\mathrm{ID}$ & Normal & Favourable & mut & wt \\
\hline 0885 & 74 & $\mathrm{~F}$ & $\mathrm{ID}$ & Normal & Intermediate & mut & mut \\
\hline 4321 & 50 & $F$ & ID & Normal & Intermediate & mut & mut \\
\hline 6789 & 68 & $M$ & $\mathrm{ID}$ & Normal & Favourable & mut & wt \\
\hline 0252 & 84 & $\mathrm{~F}$ & $\mathrm{ID}$ & Aberrant & Favourable & mut & mut \\
\hline 1421 & 66 & $F$ & $\mathrm{ID}$ & Aberrant/normal & Adverse & wt & wt \\
\hline 0682 & 56 & $\mathrm{~F}$ & $\mathrm{ID}$ & Complex aberrant & Adverse & wt & wt \\
\hline 7782 & 76 & $M$ & $\mathrm{ID}$ & Complex aberrant & Adverse & wt & wt \\
\hline 5964 & 87 & $\mathrm{~F}$ & $\mathrm{ID}$ & Complex aberrant & Adverse & wt & wt \\
\hline AML-491 [3] & 53 & $\mathrm{~F}$ & $\mathrm{R}$ & $\operatorname{del}(7)(q 21)$ & Adverse & wt & wt \\
\hline AML-579 [3] & 51 & $M$ & $\mathrm{R}$ & Normal & Adverse & mut, LOH & mut \\
\hline AML-640 & 79 & $M$ & $\mathrm{R}$ & $\mathrm{t}(11 ; 15)$ & Intermediate & mut & mut \\
\hline AML-979 & 56 & $\mathrm{~F}$ & $\mathrm{R}$ & Normal & n.a. & $w t+$ mut subclone & mut \\
\hline
\end{tabular}


of antibody binding, the median fluorescence intensity (MFI) ratio was calculated by dividing the MFI of the tested antibody by the MFI of the corresponding isotype. Antibodies were considered to bind the cells if the intensity exceeded an MFI ratio of 1.5 .

\section{Competitive binding assays}

PKH26 (Sigma-Aldrich)-labelled MOLM-13 was incubated with a 20-fold excess of red blood cells (RBCs) and antibodies. APC ahIgG (HP6017) or APC amIgG (Poly4053) was used for secondary labelling. For assays with PBMCs, calcein AM (Thermo Fisher Scientific) or CellTrace ${ }^{\mathrm{TM}}$ calcein red-orange AM (Thermo Fisher Scientific)-labelled MOLM-13 cells were incubated with a fivefold excess of PBMCs and antibodies. APC or FITC $\alpha$ hIgG (HP6017) was used for secondary antibody labelling.

\section{Platelet aggregation}

PRP was centrifuged at $15,000 \times g$ for $2 \mathrm{~min}$ to obtain platelet-poor plasma (PPP). PRP was incubated in the presence of $100 \mathrm{nM}$ antibodies, and absorbance was measured at $595 \mathrm{~nm}$ using an Infinite M100 plate reader (TECAN) for $16 \mathrm{~min}$. The percentage of aggregation was calculated as (platelet aggregation[\%] $=100 \times \frac{(\text { OD PRP - OD sample) }}{(\text { OD PRP - OD PPP })}$ [30].

\section{Antibody-dependent cellular phagocytosis (ADCP) assay}

Monocytes were enriched using a classical monocyte isolation kit (Miltenyi) and were differentiated into macrophages in the presence of $100 \mathrm{ng} / \mathrm{ml} \mathrm{MCSF}$ (Biolegend) for 5-7 days. Macrophages were labelled with calcein $\mathrm{AM}$ and incubated with CellTrace ${ }^{\mathrm{TM}}$ calcein redorange AM-labelled target cells and antibodies at $50 \mathrm{pM}$ or $50 \mathrm{nM}$ for $3 \mathrm{~h}$ at $37{ }^{\circ} \mathrm{C}$ at a 1:1 effector-to-target (E:T) ratio.

\section{Antibody-dependent cellular cytotoxicity (ADCC) assays}

NK cells were enriched using a NK cell isolation kit (Miltenyi). MOLM-13 cells were labelled with calcein AM and incubated with NK cells and antibodies for $4 \mathrm{~h}$ at $37^{\circ} \mathrm{C}$ at a 5:1 E:T ratio. In the competitive ADCC assay, NK cells were incubated with labelled MOLM-13 or Raji cells mixed with unlabelled Raji or MOLM-13 cells, respectively, at a 5:1:1 E:T:T ratio. Triton X-100 (2.5\%, Sigma-Aldrich) was used for maximum lysis. Fluorescence intensity (FI) from calcein AM release was measured using an Infinite M100 plate reader, and lysis was calculated as (specific lysis $[\%]=100 \times \frac{\mathrm{FI}(\text { antibody stimulation })-\mathrm{FI} \text { (untreated) }}{\mathrm{FI}(\max )-\mathrm{FI}(\text { target })}$. Data were fitted to a four-parameter dose-response curve.

ADCC assays of AML patient samples were performed in $\alpha$-MEM (Thermo Fisher Scientific) supplemented with
$12.5 \%$ foetal calf serum, $12.5 \%$ horse serum, $1 \%$ penicillin, $1 \%$ streptomycin, $1 \%$ glutamine (Invitrogen) and a distinct cytokine cocktail on irradiated MS-5 cells in a long-term culture as described elsewhere [31, 32]. AML cells were incubated with HD NK cells and $10 \mathrm{nM}$ antibodies for $20 \mathrm{~h}$ at $37^{\circ} \mathrm{C}$ at a 5:1 E:T ratio. Dead cells were excluded as 7-AAD (BioLegend) or LIVE/DEAD ${ }^{\mathrm{TM}}$ Fixable Aqua (Thermo Fisher Scientific)-positive cells. $\mathrm{CD}_{3}{ }^{+}$or $\mathrm{CD} 123^{+} \mathrm{AML}$ cells were determined by BV421, APC $\alpha$ hCD33 (WM53) or PE $\alpha \mathrm{hCD} 123$ (6H6) labelling, respectively. Additionally, APC-Cy7 or FITC ahCD69 (FN50) and the corresponding isotype control (MOPC-21) were used to determine the percentage of $\mathrm{CD} 9^{+}$cells. In some experiments, NK cells were labelled with CellTrace ${ }^{\mathrm{TM}}$ CFSE or CellTrace ${ }^{\mathrm{TM}}$ Far Red (both Thermo Fisher Scientific) according to the manufacturer's recommendations. Cell populations were assessed by flow cytometry, and the percentage of viable $\mathrm{CD} 33^{+}$ or $\mathrm{CD}_{123^{+}}$AML cells was normalized to the human IgG1 isotype control sample. The percentage of $\mathrm{CD}^{2} 9^{+}$ cells was normalized to the human IgG1 isotype control sample.

In the AML PDX ADCC, AML-491, AML-979, and AML-640 were incubated with NK cells and $100 \mathrm{nM}$ antibodies for $20 \mathrm{~h}$ at $37^{\circ} \mathrm{C}$ at a 5:1 E:T ratio. Cells were labelled with LIVE/DEAD Fixable Aqua, and the proportion of live mCherry ${ }^{+}$cells was determined by flow cytometry and normalized to the isotype control.

\section{In vivo engraftment experiments}

To evaluate the targeting of AML cells with leukaemia-initiating properties, ex vivo NK cell-mediated ADCC was performed using the $\alpha C D 123$ antibody, the $2 \times \operatorname{SIRP} \alpha-\alpha \mathrm{CD} 123$ fusion antibody or isotype antibody as a control, and surviving cells were used in an in vivo engraftment experiment. To this end, PDXs AML-491 and AML-579 [33, 34] were incubated with HD NK cells at an E:T ratio of 5:1 and antibodies for $20 \mathrm{~h}$. After ADCC, residual mCherry ${ }^{+}$PDX cells were separated from NK cells and quantified by fluorescence-activated cell sorting (FACS) using a FACSAria III (BD Biosciences). According to previous data [34] and assuming that the isotype control antibody did not alter LIC frequency, we injected cell numbers corresponding to 10 leukaemia-initiating cells $(10 \times$ LIC, $n=5)$ and $100 \times$ LIC $(n=5)$ for AML- 491 or $14 \times$ LIC $(n=4)$ and $140 \times$ LIC $(n=2)$ for AML-579 by counting and diluting sorted cells of the isotype control suspensions. To enable comparison between the groups, equal volumes of $\alpha \mathrm{CD} 123$ and $2 \times \operatorname{SIRP} \alpha-\alpha C D 123$ antibody ex vivo cell suspensions were sorted and injected intravenously into 10- to 12-week-old male (AML-491) or female (AML-579) NSG mice. Positive AML engraftment was analysed by in vivo 
bioluminescence imaging (BLI), and total flux was quantified as previously described [33]. Mice exhibiting a total flux greater than $5 \times 10^{7}$ photons per second were classified as exhibiting positive engraftment; mice displaying no positive imaging signal within 28 weeks after transplantation were classified as negative for engraftment. To evaluate the percentage of human $\mathrm{CD}^{+} 3^{+}$cells in peripheral blood, PE anti-human CD33 (WM53, BD Biosciences) and PE isotype control (MOPC-21, BD Biosciences) were used. Mice exhibiting any clinical signs of illness or end-stage leukaemia (total flux $>2 \times 10^{10}$ photons $/ \mathrm{s}$; hCD $33^{+}$cells in peripheral blood $>50 \%$ ) were euthanized. Three mice died in narcosis during imaging and were counted as positive according to the last imaging signal or were excluded if not engrafted.

\section{Data analysis}

Statistical evaluation was performed using GraphPad Prism versions 6.07 and 8.1.2 (GraphPad). Datasets were analysed using one-way analysis of variance (ANOVA) including a test to determine equal variances within the groups and correction for multiple testing using HolmSidak's test. Chi-squared test was used to determine whether there is a statistically significant difference in the growth of engrafted AML PDX cells. A Kaplan-Meier plot was generated to depict AML engraftment and survival by treatment group, and significance was assessed using the log-rank Mantel-Cox test. Extreme limiting dilution analysis was performed using the injected cell number and number of AML engrafted mice as inputs as previously described [35] (Figure 7; Additional file 1: Table S2). The results were considered statistically significant at the following values and are marked in the figures as follows: $p$ value $<0.05(*),<0.01(* *),<0.001$ $(* * *)),<0.0001{ }^{(* * * * *)}$.

\section{Results \\ Generation and characterization of SIRPa-aCD123 fusion antibodies}

The $1 \times$ SIRP $\alpha-\alpha C D 123$ recombinant antibody was generated by fusing the N-terminal SIRPa immunoglobulin V-like domain to the $\alpha \mathrm{CD} 123$ antibody light chain via a flexible polypeptide linker (Fig. 1A). Likewise, for $2 \times \operatorname{SIRP} \alpha-\alpha C D 123$, a second SIRP $\alpha$ domain was connected to the $\mathrm{N}$-terminus of $1 \times \mathrm{SIRP} \alpha-\alpha \mathrm{CD} 123$ (Fig. 1A). Antibodies were produced in Expi293F cells, purified from cell culture supernatants and analysed by size exclusion chromatography and SDS-polyacrylamide gel electrophoresis (Additional file 1: Figure S1AB). Thermal stability was assessed by measuring changes in the intrinsic fluorescence of the proteins using Tycho NT.6 (Additional file 1: Figure S1C). To investigate whether the $\mathrm{N}$-terminal fusion of the SIRP $\alpha$ domains alters the binding to CD123, we determined the $K_{\mathrm{D}}$ values using a Biacore assay. The $K_{\mathrm{D}}$ values were in the low nanomolar range for all constructs, indicating that the high affinity for CD123 was not affected by the fusion of the SIRP $\alpha$ domains (Fig. 1B). We further evaluated binding of the antibodies to $\mathrm{CHO}$ cells stably overexpressing human $\mathrm{CD} 47$ (hCD47) by flow cytometry (Table 2). As expected, $1 \times \mathrm{SIRP} \alpha-\alpha \mathrm{CD} 123$ and $2 \times \mathrm{SIRP} \alpha-\alpha \mathrm{CD} 123$ bound to ${ }^{+} \mathrm{CHO}$ hCD $47^{+}$cells but not to ${ }^{-} \mathrm{CHO}$ hCD $47^{-}$ cells (Fig. 1C). These binding experiments indicate that the $\alpha \mathrm{CD} 123$ and SIRP $\alpha$ domains can bind to their respective targets in the fusion antibody.

\section{SIRPa-aCD123 fusion antibodies specifically bind to $\mathrm{CD} 123^{+} \mathrm{CD} 47^{+} \mathrm{AML}$ cells}

Next, we used the CD $123^{+} \mathrm{CD} 47^{+}$AML cell line MOLM13 in a flow cytometry-based binding assay to study the dual targeting properties of the antibody constructs (Fig. 2A, Table 2). The binding of $1 \times \operatorname{SIRP} \alpha-\alpha \mathrm{CD} 123$ and $2 \times$ SIRP $\alpha-\alpha C D 123$ to MOLM-13 cells was stronger than that of the $\alpha \mathrm{CD} 123$ antibody, indicating a contribution by the SIRP $\alpha$ domain. The $\alpha$ CD19 SIRP $\alpha$ fusion antibodies mediated only weak binding to CD19- MOLM-13 cells due to some low binding of the SIRP $\alpha$ domains (Fig. 2A, Table 2). In summary, we hypothesize that the strong binding of the SIRP $\alpha-\alpha C D 123$ antibodies to MOLM-13 cells is due to avidity-dependent binding to both CD123 and CD47.

The physiological interaction of the SIRP $\alpha$ domain and CD47 is approximately 100 -fold weaker than the affinity of the $\alpha C D 123$ antibody for CD123 [26, 36]. Therefore, we postulated that the high affinity $\alpha \mathrm{CD} 123$ drives the preferential binding of SIRP $\alpha-\alpha C D 123$ fusion antibodies onto $\mathrm{CD} 123^{+} \mathrm{CD} 47^{+}$leukemic cells over $\mathrm{CD} 123^{-} \mathrm{CD} 47^{+}$ healthy cells. To test this hypothesis, we first utilized RBCs as highly abundant healthy cells expressing CD47 (Fig. 2B, Table 2).

We observed selective binding to MOLM-13 cells using the $1 \times \operatorname{SIRP} \alpha-\alpha \mathrm{CD} 123$ antibody even in the presence of a 20-fold excess of RBCs (Fig. 2B, C). $2 \times$ SIRP $\alpha-\alpha C D 123$, on the other hand, was also detected on the surface of $\mathrm{RBCs}$, indicating that the additional SIRP $\alpha$ domains can increase the competition between $\mathrm{CD} 47^{+}$MOLM-13 cells and RBCs (Fig. 2B, C). Nevertheless, the RBC targeting observed for $2 \times \operatorname{SIRP} \alpha-\alpha C D 123$ was very weak, with a binding intensity far below an MFI ratio of 1.5 (Fig. 2D). In contrast, the high affinity $\alpha \mathrm{CD} 47 \mathrm{~B} 6 \mathrm{H} 12$ antibody demonstrated a substantial on-target off-leukaemia effect, as it primarily bound to RBCs with a high MFI ratio (Fig. 2B-D). We concluded that despite carrying the SIRP $\alpha$ domains, the SIRP $\alpha-\alpha C D 123$ fusion antibodies target MOLM-13 cells more than the high affinity $\alpha \mathrm{CD} 47$ and avoid the antigen sink generated by the RBCs. 


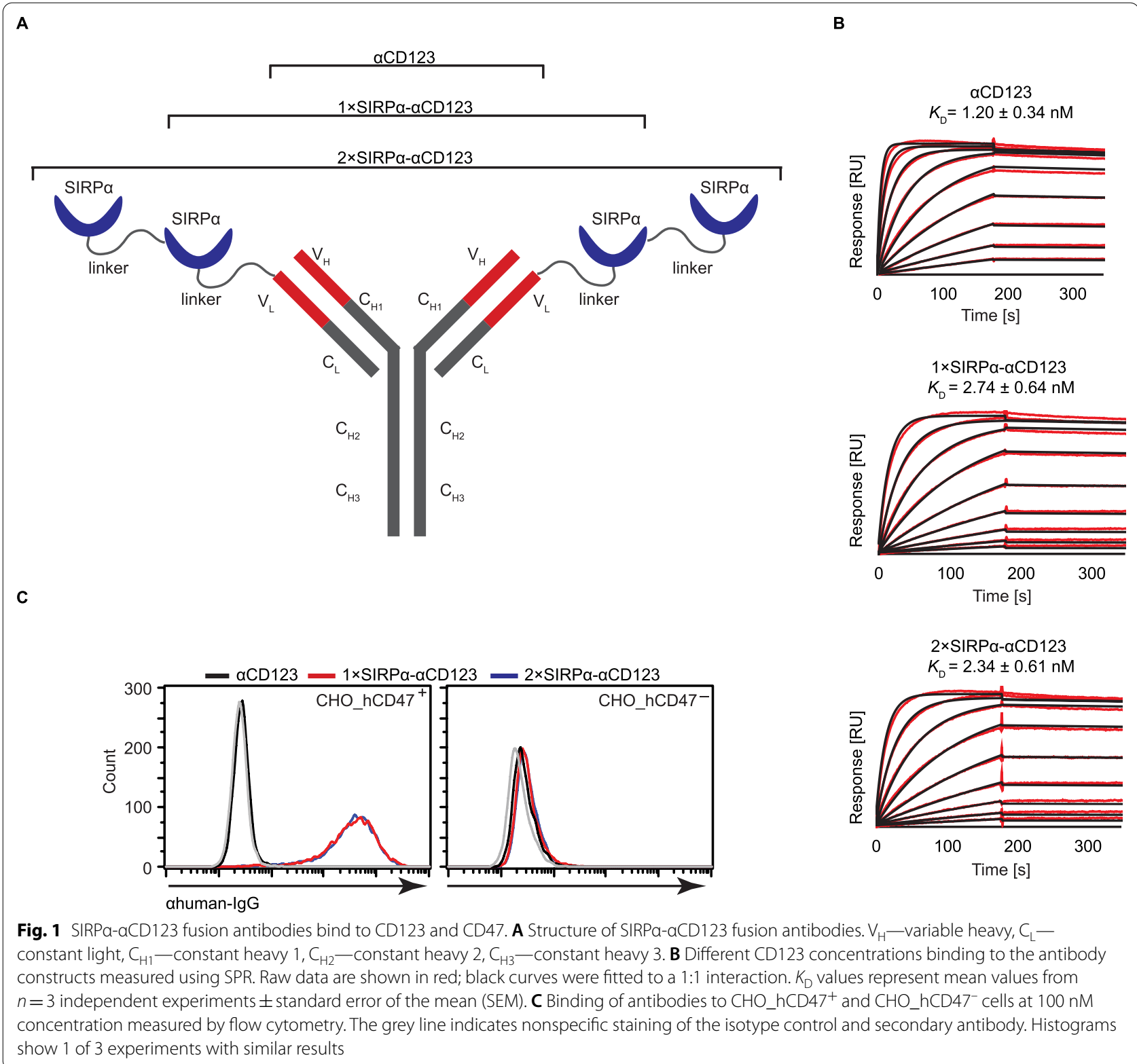

Table 2 Antigen expression levels

\begin{tabular}{lccl}
\hline Cell type & CD123 & CD47 & CD19 \\
\hline MOLM-13 & $13723 \pm 1108$ & $67703 \pm 3784$ & $30 \pm 2$ \\
Raji & $94 \pm 95$ & $170868 \pm 37029$ & $141688 \pm 19997$ \\
$\mathrm{CHO}^{\mathrm{CD} 47+}$ & $104 \pm 68$ & $1424894 \pm 329869$ & n.d. \\
$\mathrm{CHO}^{\mathrm{CD} 47-}$ & $159 \pm 50$ & $532 \pm 35$ & n.d. \\
RBC & $106 \pm 33$ & $33841 \pm 2221$ & n.d.
\end{tabular}

Determined using QIFIKIT. Data are shown as the means \pm SEM $(n=2-3)$. Not determined (n. d.)
In another set of experiments, we investigated the selective binding of our antibodies to MOLM-13 cells in the presence of HD PBMCs (Fig. 2E). From PBMCs, plasmacytoid dendritic cells express CD123 and are targeted by the $\alpha \mathrm{CD} 123$ antibody CSL362 [37]. We also found that some of our $\alpha \mathrm{CD} 123$ binds to PBMCs; however, the majority of the antibodies still bound to MOLM-13 cells (Fig. 2E). The $1 \times$ SIRP $\alpha-\alpha C D 123$ antibody bound PBMCs to a considerable extent, but higher selective binding to MOLM-13 cells was observed compared to the $\alpha$ CD47 Hu5F9-G4 clone. $2 \times$ SIRP $\alpha-\alpha C D 123$ targeted MOLM-13 cells similarly to $\alpha$ CD47 Hu5F9-G4. However, when we analysed binding of the antibodies to PBMCs 


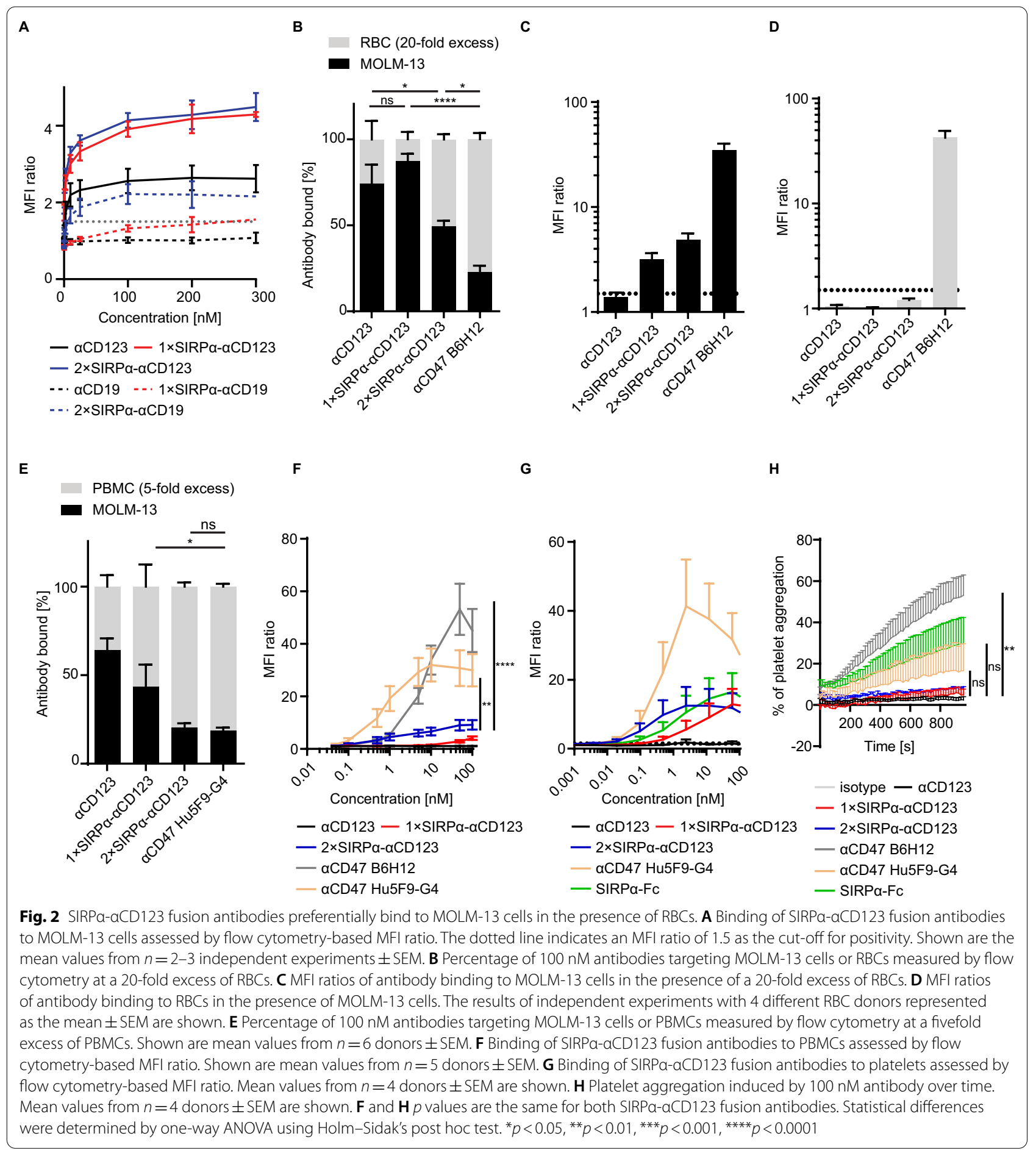

alone, we observed that our fusion antibodies bound PBMCs significantly less than the $\alpha \mathrm{CD} 47$ Hu5F9-G4 and $\mathrm{B} 6 \mathrm{H} 12$ antibodies (Fig. 2F). These data indicate that although our fusion antibodies seem to target PBMCs more than RBCs, they bind to PBMCs to a lesser extent than the high affinity $\alpha C D 47$ antibodies.
In addition to binding to RBCs, CD47-targeting agents have been reported to bind platelets and interfere with their function [38, 39]. We therefore investigated whether our SIRP $\alpha-\alpha C D 123$ fusion antibodies target platelets and induce their aggregation (Fig. 2G-H). Indeed, SIRP $\alpha-$ $\alpha C D 123$ fusion antibodies bound to platelets similarly to 
the SIRP $\alpha$-Fc construct but less than the $\alpha \mathrm{CD} 47 \mathrm{Hu} 5 \mathrm{~F} 9$ G4 control (Fig. 2G). However, SIRP $\alpha-\alpha C D 123$ antibodies did not induce aggregation of platelets, unlike SIRP $\alpha-\mathrm{Fc}$, $\alpha \mathrm{CD} 47$ Hu5F9-G4 and especially $\alpha \mathrm{CD} 47 \mathrm{~B} 6 \mathrm{H} 12$ antibodies (Fig. 2H). These experiments suggest that binding of the constructs does not directly correlate with a functional effect and indicate that our SIRP $\alpha-\alpha C D 123$ fusion antibodies do not stimulate platelet aggregation.

\section{SIRPa-aCD123 fusion antibodies block CD47 and induce phagocytosis of MOLM-13 cells in vitro}

SIRP $\alpha-\alpha C D 123$ fusion antibodies were designed to inhibit the CD47-SIRP $\alpha$ axis locally on CD123+ cells. To examine this, we performed a blocking assay using labelled $\alpha C D 47$ antibodies that interfere with the binding of SIRP $\alpha$. Despite the weak affinities of the SIRP $\alpha$ domains, $1 \times \operatorname{SIRP} \alpha-\alpha C D 123$ and $2 \times \operatorname{SIRP} \alpha-\alpha C D 123$ were able to block CD47 molecules on MOLM-13 cells. Not surprisingly, maximum blockade was observed with the high affinity $\alpha \mathrm{CD} 47$ antibody. In comparison, $1 \times$ SIRP $\alpha-\alpha C D 123$ did not block CD47 on CD123- Raji cells, and $2 \times \mathrm{SIRP} \alpha-\alpha \mathrm{CD} 123$ minimally blocked CD47 (Additional file 1: Figure S2A), indicating that binding of the $\alpha$ CD123 moiety to target cells is required for efficient disruption of the CD47-SIRP $\alpha$ axis.

We next examined whether CD47 blockade with concomitant engagement of FcyRs stimulates the ADCP of MOLM-13 cells by HD-derived macrophages (Fig. 3B). Indeed, phagocytosis was significantly boosted by $1 \times \operatorname{SIRP} \alpha-\alpha C D 123$ compared to $\alpha C D 123$. $2 \times \operatorname{SIRP} \alpha-$ $\alpha C D 123$ also induced elevated phagocytosis, but this was not statistically significant. In contrast, $\alpha \mathrm{CD} 47 \mathrm{did}$ not stimulate phagocytosis either alone or in combination with $\alpha C D 123$ in this setting. The respective $\alpha C D 19$ controls did not have an effect on phagocytosis. In summary, SIRP $\alpha-\alpha C D 123$ fusion antibodies boost ADCP in MOLM-13 cells, whereas $\alpha$ CD123 and $\alpha$ CD 47 antibodies alone lack this ability.

\section{SIRPa-aCD123 fusion antibodies induce enhanced phagocytosis of patient-derived AML cells by allogeneic and autologous macrophages in vitro}

We further investigated the stimulation of phagocytosis by SIRP $\alpha-\alpha C D 123$ antibodies using primary AML patient-derived blasts as targets and allogeneic or autologous monocyte-derived macrophages as effector cells (Fig. 4A, B). We observed enhanced overall phagocytosis by primary AML cells compared to MOLM-13 cells. Allogeneic macrophages from HDs mediated significantly higher ADCP with the $1 \times \operatorname{SIRP} \alpha-\alpha C D 123$ fusion antibody compared to $\alpha C D 123$. The $2 \times \operatorname{SIRP} \alpha-$ $\alpha \mathrm{CD} 123$ had a similar effect (Fig. 4A). More importantly, these results were confirmed in the autologous setting (Fig. 4B). Phagocytosis mediated by $1 \times$ SIRP $\alpha-\alpha C D 123$ and $2 \times$ SIRP $\alpha-C D 123$ was significantly higher than that mediated by $\alpha$ CD123. $\alpha \mathrm{CD} 47$ antibodies B6H12 and Hu5F9-G4 alone or in combination with $\alpha$ CD123 antibody induced similar ADCP as SIRP $\alpha-\alpha C D 123$ fusion antibodies. When comparing SIRP $\alpha-C D 123$ fusion antibodies to similar $\alpha$ CD33-based constructs [18], we did not observe significant differences in the ability to induce phagocytosis of AML cells (Fig. 4B). Taken together, these data reveal that SIRP $\alpha-\alpha C D 123$ fusion antibodies
A

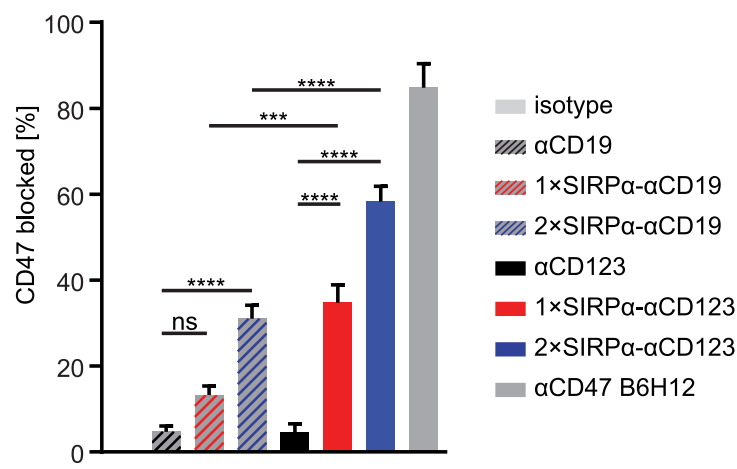

B

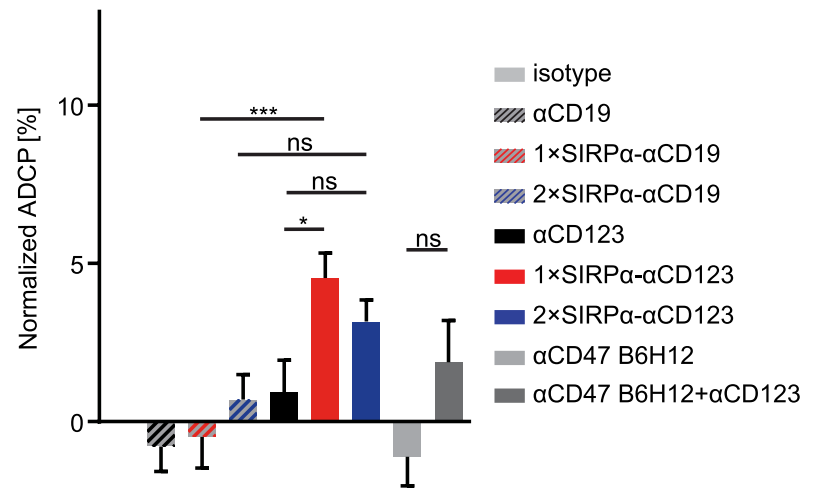

Fig. 3 SIRPa-aCD123 fusion antibodies block CD47 and stimulate phagocytosis of MOLM-13. A CD47 blockade on MOLM-13 cells with $100 \mathrm{nM}$ antibodies determined by FITC aCD47 binding using flow cytometry. Background fluorescence was subtracted from the FITC aCD47 signal and normalized to isotype to calculate the CD47 blockade. Mean \pm SEM of $n=4$ independent experiments. B ADCP of MOLM-13 cells at a 50 pM concentration of antibodies after $3 \mathrm{~h}$ at an E:T ratio of 1:1. ADCP was measured as the percentage of double-positive cells from macrophages and normalized to the isotype control. Bar charts represent the mean \pm SEM from $n=7$ different donors. Statistical differences were determined by one-way ANOVA using Holm-Sidak's post hoc test. ${ }^{*} p<0.05,{ }^{* * *} p<0.001,{ }^{* * * *} p<0.0001$, not significant (ns) 


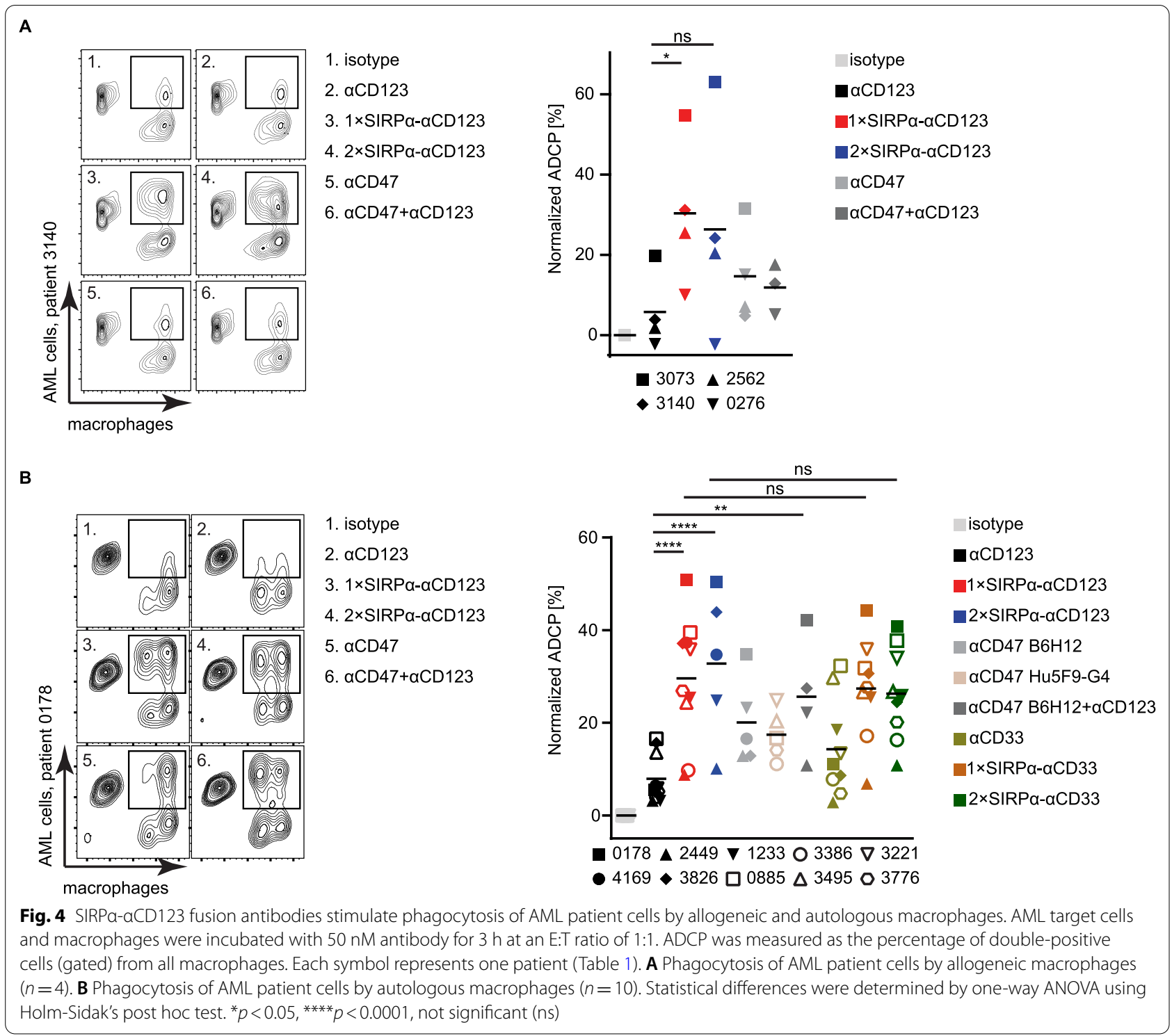

represent an effective tool to overcome the CD47-mediated inhibition of phagocytosis in AML.

\section{SIRPa-aCD123 fusion antibodies induce NK cell-mediated specific lysis of $A M L$ cells in vitro}

ADCC by NK cells is one of the primary mechanisms by which IgG1 antibodies induce the elimination of antibody-bound cells in addition to macrophage-mediated ADCP [40]. Therefore, we analysed specific lysis of MOLM-13 cells by HD-derived NK cells (Fig. 5A). $\alpha \mathrm{CD} 123$ induced moderate dose-dependent lysis of MOLM-13, whereas $1 \times \operatorname{SIRP} \alpha-\alpha C D 123$ and $2 \times \operatorname{SIRP} \alpha-$ $\alpha C D 123$ were more potent. We postulated that SIRP $\alpha$ $\alpha C D 123$ fusion antibodies are more efficient due to the avidity-dependent targeting of both CD123 and
CD47. The respective $\alpha \mathrm{CD} 19$ controls induced lysis of MOLM-13 cells only at high concentrations, which can be attributed to autonomous targeting of CD47 by the fused SIRP $\alpha$ domain. Nevertheless, the half maximal effective concentration $\left(\mathrm{EC}_{50}\right)$ was considerably lower for $2 \times \operatorname{SIRP} \alpha-\alpha C D 123(19.1 \mathrm{pM})$ than for the $2 \times \operatorname{SIRP} \alpha$ $\alpha C D 19$ analogue (192.1 pM), demonstrating target antigen-specific cytotoxicity. This was further demonstrated in a competitive ADCC assay in which CD123 ${ }^{+}$MOLM13 cells were mixed with $\mathrm{CD} 123^{-}$Raji cells (Additional file 1: Figure S2B). In this setting, Raji cells were not lysed by $1 \times$ SIRP $\alpha-\alpha C D 123$ and $2 \times$ SIRP $\alpha-\alpha C D 123$ only exerted an effect at high concentrations. In summary, although independent binding of the SIRP $\alpha$ domains can cause some lysis of target cells at high concentrations, we 


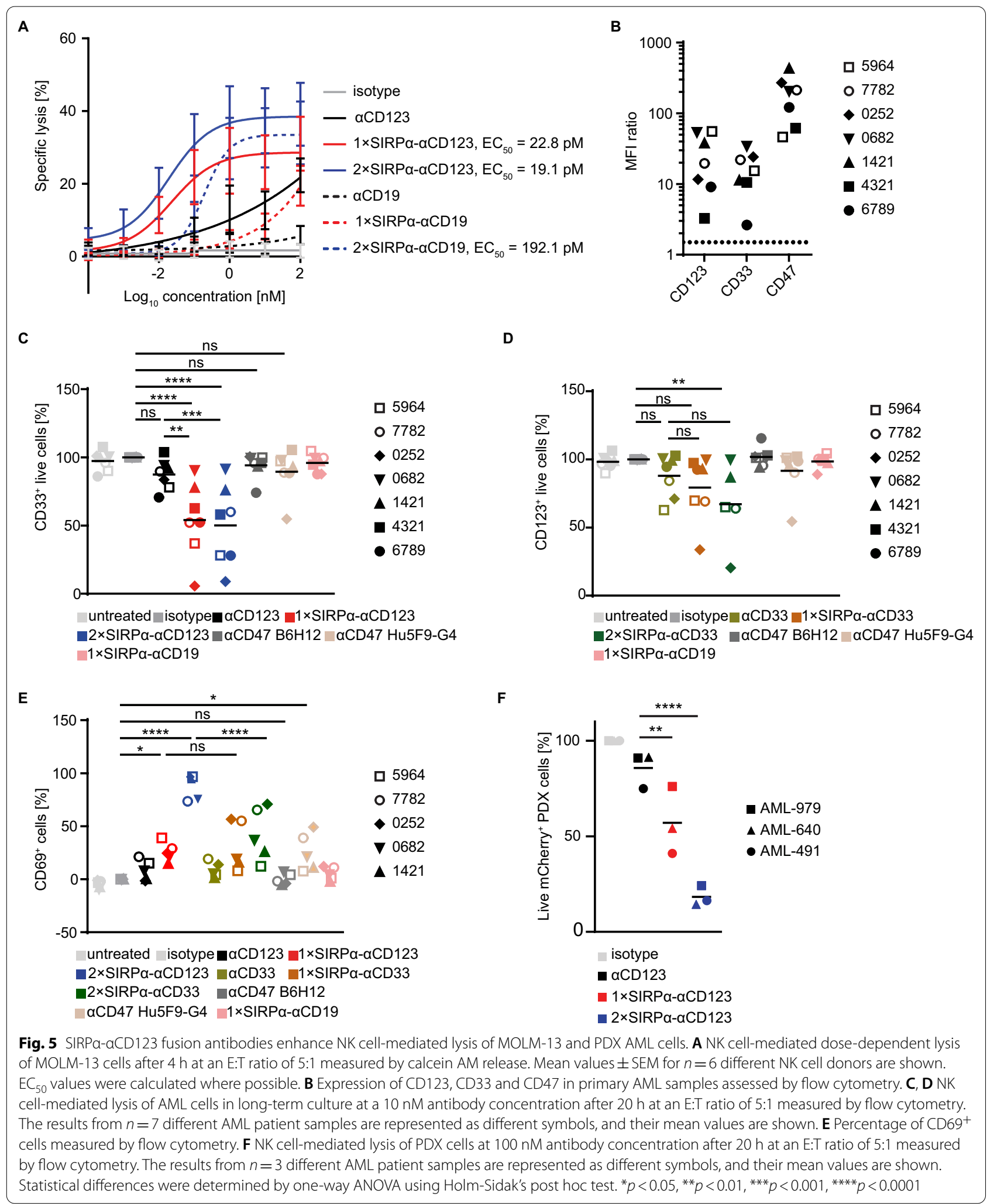


consider high affinity $\alpha \mathrm{CD} 123$ binding to be a prerequisite for targeting by SIRP $\alpha-\alpha C D 123$ fusion antibodies.

The ability of SIRP $\alpha-\alpha C D 123$ fusion antibodies to activate NK cells was further investigated using AML patient cells. First, we used blasts from primary AML patients (Fig. 5B) in a long-term culture system with HD-derived NK cells as effectors [31]. Compared to isotype controls and $\alpha \mathrm{CD} 123,1 \times \mathrm{SIRP} \alpha-\alpha \mathrm{CD} 123$ and $2 \times \mathrm{SIRP} \alpha-\alpha \mathrm{CD} 123$ antibodies significantly boosted the cytotoxicity by NK cells, leading to reduced numbers of AML cells (Fig. 5C). As expected, the $\alpha \mathrm{CD} 47$ antibodies $\mathrm{B} 6 \mathrm{H} 12$ and Hu5F9G4 and the $1 \times$ SIRP $\alpha$ CD19 control molecule did not stimulate lysis of AML cells (Fig. $5 \mathrm{C}$ ). From the $\alpha \mathrm{CD} 33$ constructs, only the $2 \times \operatorname{SIRP} \alpha \alpha C D 33$ analogue induced significant lysis of AML cells compared to the isotype control (Fig. 5D). When analysing the NK cell population of the ADCC samples, we observed a significant upregulation of the activation marker CD69 with $1 \times$ - and $2 \times \operatorname{SIRP} \alpha-\alpha C D 123$ (Fig. 5E). Treatment with $2 \times \operatorname{SIRP} \alpha-$ $\alpha \mathrm{CD} 123$ induced especially potent CD69 upregulation, which was also significantly greater than that induced by the $2 \times \operatorname{SIRP} \alpha \alpha \mathrm{CD} 33$ analogue (Fig. 5E). Interestingly, the $\alpha \mathrm{CD} 47$ antibody Hu5F9-G4 induced slight upregulation of CD69 (Fig. 5E). Together, these results demonstrate that in addition to highly effective Fc $\gamma R$-dependent ADCC stimulation, SIRP $\alpha-\alpha C D 123$ antibodies might further activate NK cells via mechanisms related to CD47 blockade.

Next, we used AML PDX cells as target cells. Here, we observed that $1 \times \operatorname{SIRP} \alpha-\alpha \mathrm{CD} 123$ and $2 \times \operatorname{SIRP} \alpha-\alpha \mathrm{CD} 123$ both dramatically increased the lysis of AML PDX cells compared to $\alpha \mathrm{CD} 123$ (Fig. 5E). This again highlights that our fusion antibodies enhance NK cell-mediated lysis of patient-derived AML cells.

\section{SIRPa-aCD123 fusion antibodies have the potential to target AML stem cells}

Specific targeting of AML LSCs is needed to prevent relapse and enhance the rate and duration of response to therapy in patients. We hypothesized that SIRP $\alpha-$ $\alpha \mathrm{CD} 123$ fusion antibodies would efficiently eliminate $\mathrm{CD} 123^{\text {high }} \mathrm{CD} 47^{\text {high }}$ LSCs due to the avidity-dependent binding of the $\alpha C D 123$ and SIRP $\alpha$ moieties. Xenograft mouse models have been widely used to investigate leukaemia-initiating cells (LICs) as surrogates for LSCs [41, 42]. To evaluate the impact of HD NK cell-dependent cytotoxicity of our antibodies on LICs, we performed an in vivo engraftment assay using residual AML PDX cells that survived an ex vivo ADCC assay (Fig. 6A). We expect that LICs are killed more efficiently with SIRP $\alpha$ $\alpha C D 123$ fusion antibodies than with $\alpha \mathrm{CD} 123$ antibodies in the ex vivo ADCC assay and thus lead to reduced engraftment of AML cells. To this end, PDX cells from two AML patients were incubated with NK cells and isotype control, $\alpha \mathrm{CD} 123$ or $2 \times \mathrm{SIRP} \alpha-\alpha \mathrm{CD} 123$ (Additional file 1: Figure S3). Only the $2 \times \operatorname{SIRP} \alpha-\alpha C D 123$ fusion antibody was used as it showed superior killing of AML PDX cells (Fig. 5F). After this ADCC, surviving PDX cells were sorted and injected into NSG mice at two doses corresponding to 10 leukaemia-initiating cells $(10 \times$ LIC) or $100 \times$ LIC. AML engraftment was analysed by in vivo BLI and peripheral blood analysis.

As expected, all mice that received residual cells from isotype control-treated AML-491 ADCC culture exhibited PDX cell engraftment soon after transplantation [10 $\times$ LIC: $28-49$ days post injection $(\mathrm{dpi}), n=5$; $100 \times$ LIC: 33 dpi, $n=5$ ], whereas treatment with the $\alpha C D 123$ antibody slightly delayed the time to positive engraftment $(10 \times$ LIC: $62-91 \mathrm{dpi}, n=5$; AML-491 $100 \times$ LIC: 49 dpi, $n=4$ ) (Fig. 6B-F). Importantly, residual cells from $2 \times \operatorname{SIRP} \alpha-\alpha C D 123$ ADCC cultures exhibited a dramatically reduced engraftment capacity, with only one animal in the $10 \times$ LIC group (114 dpi) and none in the $100 \times$ LIC group showing positive engraftment (Fig. 6B-F). All mice with positive engraftment reached end-stage leukaemia with high BLI signals and hCD33 ${ }^{+}$ cells in peripheral blood (Fig. 6; Additional file 1: Figure S5). AML-579 cells were injected at slightly higher doses of $14 \times$ LIC and $140 \times$ LIC, but the results were similar to those observed for AML-491 (Additional file 1: Figures S4 and S5).

We used the extreme limiting dilution analysis algorithm to determine whether the nearly absent engraftment in the $2 \times \operatorname{SIRP} \alpha-\alpha C D 123$ condition was due to specific LIC targeting or a lower number of injected residual cells [35]. Even though all mice in the isotype and $\alpha \mathrm{CD} 123$ treatment groups exhibited engraftment, a significant difference in the estimated LIC frequencies was detected between $\alpha C D 123$ and $2 \times$ SIRP $\alpha-\alpha C D 123$ for AML-491 (Fig. 7A, B; Additional file 1: Table S2). We concluded that while $2 \times \operatorname{SIRP} \alpha-\alpha \mathrm{CD} 123$ markedly reduces the number of bulk AML cells, it targets leukemic stem cells with an even higher preference.

\section{Discussion}

The ubiquitously expressed surface marker CD47 interacts with the SIRP $\alpha$ receptor to inhibit myeloid cell-mediated phagocytosis of autologous cells $[4,14,15]$. Blocking the CD47-SIRP $\alpha$ checkpoint as an anticancer therapy is under intense investigation since CD47 is overexpressed on AML as well as on various other cancer types $[5,10$, 43]. However, ubiquitous expression of CD47 creates an antigen sink that can sequester CD47-targeting agents and reduce the effective dose. Moreover, nonspecific targeting can cause toxicities to healthy cells, as CD47 has various roles in physiological tissue homeostasis [44]. For 


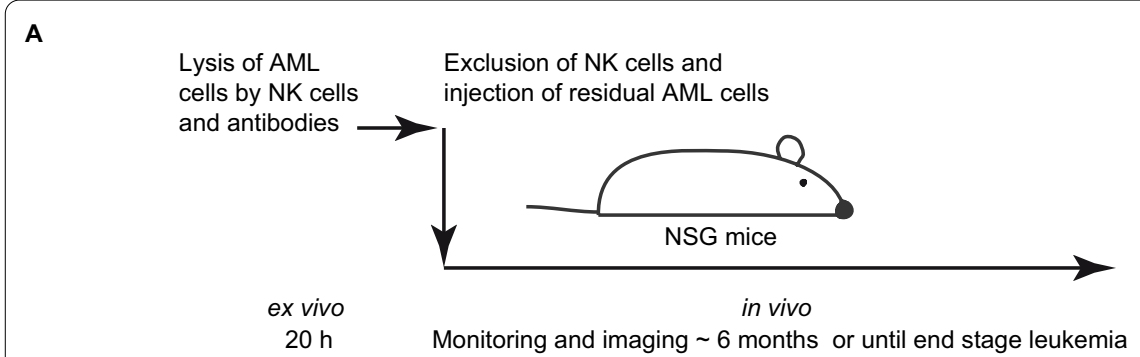

B

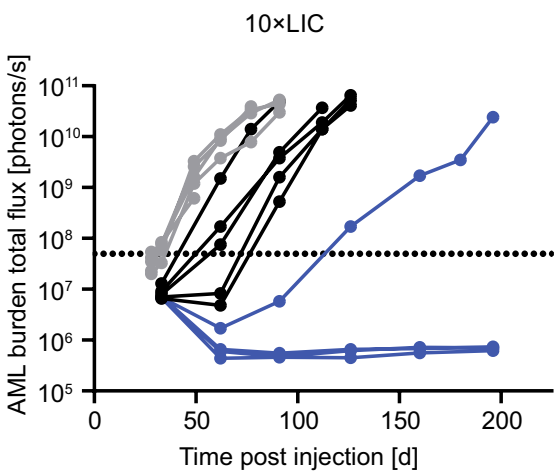

D

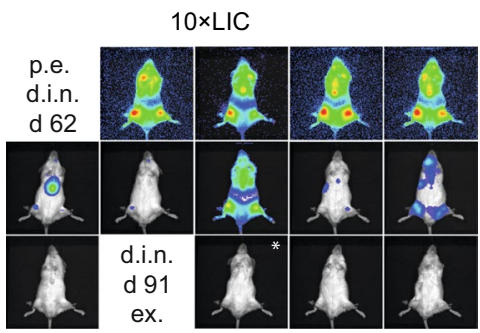

F

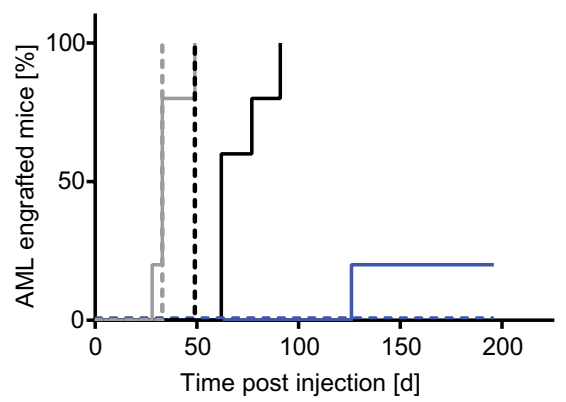

C

$100 \times$ LIC

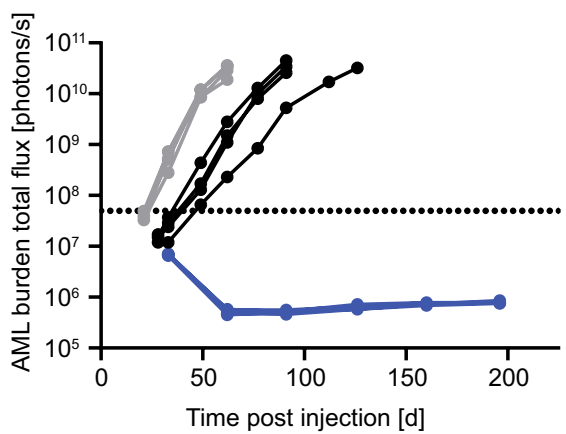

10×LIC

$\rightarrow-$ isotype, $n=5$

\begin{tabular}{l|l}
$\rightarrow \alpha \mathrm{CD} 123, n=5$ & ns \\
$\rightarrow-2 \times \operatorname{SIRP} \alpha-\alpha C D 123, n=4$
\end{tabular} \mid ns $\mid$ ns

100×LIC

$\rightarrow$ isotype, $n=5$

$n=4 \quad$ ns

$\rightarrow 2 \times \operatorname{SIRPa}-\alpha \operatorname{CD} 123, n=5$ |*

E

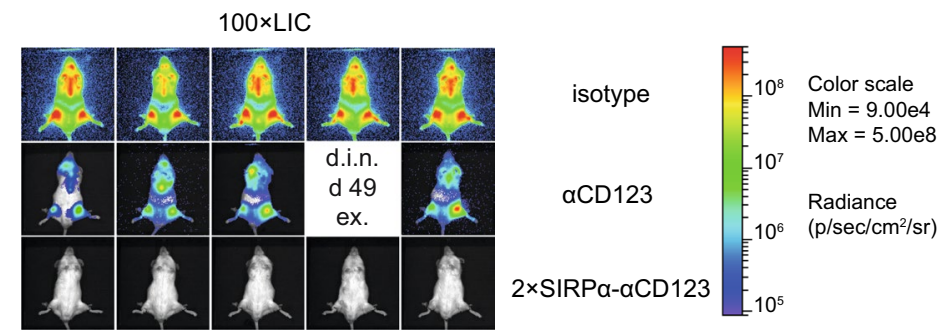

G

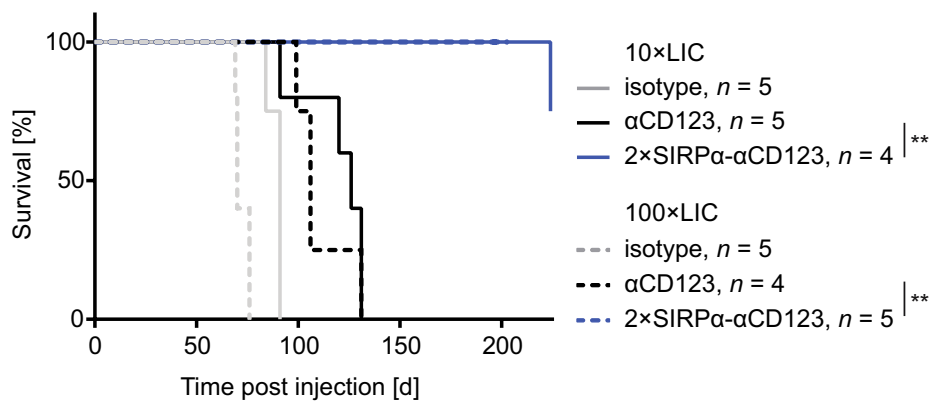

Fig. 6 Ex vivo treatment with $2 \times$ SIRPa-aCD123 prevents outgrowth of AML-491 PDX cells in vivo. A Experimental design of the engraftment assay. Residual AML cell from ADCC in (Additional file 1: Figure 3A, B) was FACS sorted, and equal volumes were injected intravenously into NSG mice. Mice were monitored using in vivo BLI. B, C AML burden in individual mice of the $10 \times$ LIC and $100 \times$ LIC groups measured by BLI. The dotted line indicates a total flux of $5 \times 10^{7}$ photons/s as the cut-off for evaluating positive AML engraftment. Statistical analysis was performed using Chi-squared test. Representative images of mice injected with $10 \times$ LIC (D) and $100 \times$ LIC (E) on day (d) 62 . Mice that died in narcosis during imaging (d.i.n.) were counted as positive if the last imaging signal showed positive engraftment (p. e.) or were excluded from analysis (ex.) if not engrafted. F Kaplan-Meier curve of AML-491 engraftment analysed by BLI. (G) Kaplan-Meier curves showing survival of mice. Statistical significance was calculated using the log-rank test. ${ }^{*} p<0.05,{ }^{* *} p<0.01$, not significant (ns) 
A

\begin{tabular}{|cccc|}
\hline & Injected cells & $\begin{array}{c}\text { Mice injected } / \\
\text { engrafted }\end{array}$ & $\begin{array}{c}\text { Estimated LIC frequency } \\
(95 \% \text { confidence interval })\end{array}$ \\
\hline isotype & 180000 & $5 / 5$ & $1 / 1$ \\
& 18000 & $5 / 5$ & $(1 / 1-1 / 22575)$ \\
\hline aCD123 & 26000 & $4 / 4$ & $1 / 1$ \\
& 2600 & $5 / 5$ & $(1 / 1-1 / 3261)$ \\
\hline \multirow{2}{*}{ 2×SIRPa- $\alpha$ CD123 } & 4000 & $5 / 0$ & $1 / 21399$ \\
& 400 & $4 / 1$ & $(1 / 2786-1 / 164397)$ \\
\hline
\end{tabular}

B

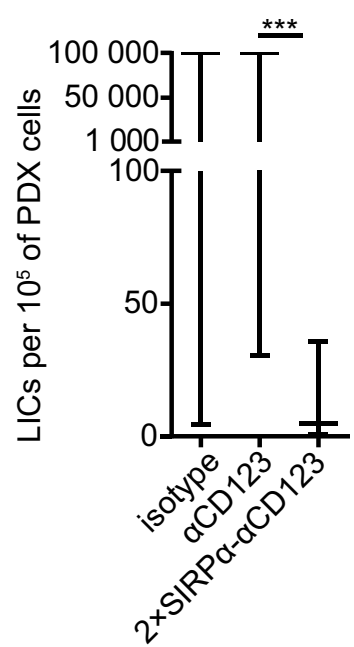

Fig. 7 LIC frequencies of AML-491 after NK cell-mediated lysis with the $2 \times$ SIRPa-aCD123 fusion antibody. A Engraftment at each injected cell dose for each antibody. Residual AML cells were counted during cell sorting before injection. B LIC frequencies were estimated using extreme limiting dilution analysis software [35]. Horizontal lines indicate the estimated LIC frequencies, and the bars indicate $95 \%$ confidence intervals

example, the CD47 ligand SIRPY is expressed on human $\mathrm{T}$ cells, and targeting CD47 with a mAb has been shown to affect human $\mathrm{T}$ cell responses [45].

The most serious side effects reported from CD47targeting agents in clinical trials are anaemia and thrombocytopenia [39, 46-49]. The SIRP $\alpha-\alpha C D 123$ antibodies presented here specifically bind to the AML cell line MOLM-13 in the presence of excess RBCs, in contrast to the high-affinity CD47-targeting antibody B6H12. These results agree with previous reports where similar constructs targeting CD33 and CD20 avoid the CD47 sink generated by RBCs $[17,18]$. We also observed that SIRP $\alpha-\alpha C D 123$ antibodies targeted PBMCs more than RBCs. The low-affinity SIRP $\alpha$-dependent binding to PBMCs might, however, not lead to activation of macrophages or NK cells based on our results with SIRP $\alpha-\alpha C D 19$ control molecules in experiments with MOLM-13 cells and primary AML cells. Importantly, although the SIRP $\alpha-\alpha C D 123$ fusion antibodies also bind platelets, they do not induce any aggregation, unlike other CD47-targeting molecules tested herein. The underlying reason for this might be a combination of relatively low-affinity binding of the SIRP $\alpha$ domain to CD47 as well as different steric features of the antibody constructs.

Despite the low-affinity binding of the SIRP $\alpha$ domains, SIRP $\alpha-\alpha C D 123$ fusion antibodies were able to induce the same or even higher phagocytosis than high affinity $\alpha \mathrm{CD} 47$ either alone or in combination with $\alpha \mathrm{CD} 123$. This is in line with the well-known synergy between CD47-SIRPa axis disruption and prophagocytic signals
$[8,10,50-52]$ and supports the rationale of combining CD47 blockade and Fc $\gamma R$ stimulation into one molecule.

AML LSCs reside in specific niches in the bone marrow [53]. Antibodies can freely access the bone marrow through sinusoidal clefts and therefore represent a promising therapeutic strategy for targeting LSCs in their microenvironment [54]. CD33-targeting gemtuzumab ozogamicin is currently the only antibody-based therapy approved for AML [55]. Unfortunately, only some patients are likely to benefit from gemtuzumab ozogamicin [56, 57]. CD33/CD47 cotargeting has been previously preclinically investigated $[18,58]$. However, bivalent mAbs against CD33 have been shown to internalize upon cross-linking, which can compromise the immune response $[59,60]$. Expression of CD33 on LSCs is also associated with variability, which might affect therapeutic outcomes [20,61]. Our results indicate that the SIRP $\alpha-\alpha C D 123$ constructs are comparable to $\alpha C D 33-$ based fusion antibodies in inducing autologous ADCP or allogenic $\mathrm{ADCC}$. Interestingly, we observed much higher activation of NK cells in response to $2 \times$ SIRP $\alpha-\alpha C D 123$ than with the $\alpha \mathrm{CD} 33$ analogue. Whether this was due to CD33-related internalization effects or other reasons remains to be investigated, but we consider $\alpha \mathrm{CD} 123$ based constructs promising candidates next to $\alpha \mathrm{CD} 33$ targeting antibodies.

Because chemorefractory LSCs build a reservoir for relapse, elimination of these cells is essential for AML treatment $[1,2]$. In younger adults, a lower percentage of $\mathrm{CD}_{123^{+}}$LSCs at diagnosis is correlated with a better response to treatment and survival [62]. Similarly, in 
older patients who are fit for intensive chemotherapy, survival was higher in those who displayed lower levels of $\mathrm{CD}_{123^{+}}$LSCs [63]. Therefore, eliminating or reducing the numbers of $\mathrm{CD}_{123}{ }^{+}$LSCs might lead to more durable responses and prolonged survival. We show here that compared to $\alpha \mathrm{CD} 123$, SIRP $\alpha-\alpha C D 123$ antibodies exhibit increased targeting efficacy of $\mathrm{CD} 123^{+} \mathrm{CD} 47^{+}$ AML cells due to avidity-dependent binding to both antigens. Our fusion antibodies could take advantage of the high expression of both CD123 and CD47 on LSCs and effectively address this population. Indeed, we observed an extreme reduction in the engraftment of AML after an ex vivo ADCC assay with the $2 \times \operatorname{SIRP} \alpha-\alpha C D 123$ antibody, as our antibodies stimulated NK cell-mediated cytotoxic lysis of AML LSCs. The increased avidity of SIRP $\alpha-\alpha C D 123$ antibodies thus provides the opportunity to preferentially target and eliminate AML LSCs.

Because of avidity-dependent binding to CD123 and CD47, SIRP $\alpha-\alpha C D 123$ antibodies could further target malignant LSCs cells over healthy haematopoietic stem cells, which express low levels of CD47 and minimal amounts of CD123 [5, 19, 21, 64]. The $2 \times \operatorname{SIRP} \alpha-$ $\alpha C D 123$ fusion antibody facilitated the most potent NK cell activation in our assays, and only this antibody was evaluated in LSC targeting experiments. To further analyse the safety and efficacy of the molecules and to determine whether the $1 \times-$ or $2 \times \operatorname{SIRP} \alpha-\alpha C D 123$ fusion format would be favourable in future clinical trials, assessing competitive targeting of patient-derived LSCs and healthy haematopoietic stem cells would be very pertinent.

While we are the first to combine CD123 and CD47 targeting, other therapeutic molecules have been developed against CD123 alone [65-67]. Talacotuzumab is an $\alpha C D 123$ antibody with a modified Fc region for enhanced ADCC [37, 68]. Unfortunately, talacotuzumab showed limited in vivo efficacy in clinical studies, which has been associated with the compromised NK cell activity in MDS and AML [69-71]. This suggests that recruiting other immune cells, such as macrophages, could stimulate a broader response to antibody-based CD123-targeting therapies. The benefit of activating macrophages in AML has been demonstrated by the $\alpha \mathrm{CD} 47$ antibody magrolimab in combination with azacytidine [8]. Recent data additionally suggest that upon activation, NK cells can upregulate SIRP $\alpha$, which leads to strong inhibition of cytotoxicity when interacting with CD47 on the surface of target cells [72]. An effective blockade of CD47 signalling could therefore be the reason we observed an extremely potent upregulation of CD69 on NK cells in response to $2 \times \operatorname{SIRP} \alpha-\alpha C D 123$ treatment. This was also indicated by the slight increase in the percentage of $\mathrm{CD} 9^{+}$cells when the $\alpha \mathrm{CD} 47$ antibody Hu5F9-G4 was used. A growing body of evidence indicates that adaptive immunity, especially the activation of $\mathrm{CD} 8^{+} \mathrm{T}$ cells, further contributes to the effects observed in response to CD47-SIRP $\alpha$ inhibition [73-75]. As SIRP $\alpha-\alpha C D 123$ fusion antibodies improve phagocytosis of AML patient cells compared to $\alpha \mathrm{CD} 123$ while still initiating strong NK cell activation, we propose that SIRP $\alpha-\alpha C D 123$ fusion antibodies stimulate a much broader immune response, including a long-lasting T-cell response.

\section{Conclusions}

In summary, we demonstrated that SIRP $\alpha-\alpha C D 123$ antibodies specifically target LSCs, mediate their efficient clearance and stimulate phagocytosis of AML while restricting CD47-related on-target off-leukaemia toxicity. These encouraging results establish SIRP $\alpha-\alpha C D 123$ antibodies as a promising approach for LSC targeting for prolonged remission in AML patients. Future in vivo studies using an appropriate AML mouse model are necessary for the translation of this approach into a clinical setting.

\begin{abstract}
Abbreviations
AML: Acute myeloid leukaemia; LSC: Leukemic stem cell; SIRPa: Signal regulatory protein alpha; FcyR: Fcy receptor; MDS: Myelodysplastic syndrome; OR Objective response; CR: Complete remission; NK: Natural killer; $V_{L}:$ Variable light; $V_{H}$ : And variable heavy; $S D S$ : Sodium dodecyl sulphate; $\mathrm{EC}_{50}$ : Half maximal effective concentration; PCR: Polymerase chain reaction; $K_{D}$ : Equilibrium dissociation constant; $\mathrm{CHO}$ : Chinese hamster ovary; PBMC: Peripheral blood mononuclear cells; PDX: Patient-derived xenograft; NSG: NOD/SCID gamma null mice; MFI: Median fluorescence intensity; RBC: Red blood cells; E:T: Effector-to-target; LIC: Leukaemia-initiating cell; BLI: Bioluminescence imaging; ANOVA: Analysis of variance; ADCP: Antibody-dependent cellular phagocytosis; ADCC: Antibody-dependent cellular cytotoxicity; HD: Healthy donor; FACS: Fluorescence-activated cell sorting.
\end{abstract}

\section{Supplementary Information}

The online version contains supplementary material available at https://doi. org/10.1186/s13045-021-01163-6.

Additional file 1. Supplementary tables and figures.

\section{Acknowledgements}

The authors are grateful to Bettina Brauchle for help with the AML patient material and to Manuel Albanese, Marcel Stern and Oliver Keppler for help with the leukoreduction chamber material. We thank Maike Fritschle and Fabian Klein for technical assistance in the in vivo experiment, Daniel Bergér for help with the assay setup and Vindi Jurinovic for advice on statistical analysis. We acknowledge the iFlow Core Facility of the university hospital Munich (INST 409/225-1 FUGG) for assistance with the generation of flow cytometry data.

\section{Authors' contributions}

$\mathrm{BV}, \mathrm{BH}, \mathrm{SS}$ contributed equally to this work. ST, NCF and KPH designed the experiments and interpreted the data. ST generated and characterized the molecules and performed functional assays with cell lines and patient materials and data analysis. SS contributed to ADCP and SPR analysis and helped with interpreting the data. BV and IJ provided PDX cells, designed the in vivo engraftment assay and performed the experiments after ex vivo ADCC. BV 
analysed the results of the in vivo engraftment experiment. $\mathrm{BH}$ performed experiments with PBMCs and platelets and contributed to autologous ADCP results. AM performed the AML long-term ADCC experiments. EP generated molecules. AR, CA, BT and MS provided AML patient material. AL performed PBMC binding studies. AH provided the leukoreduction chamber material. MS interpreted the data and provided critical feedback and support. ST and NCF wrote the manuscript with input from BV, MS and KPH. KPH supervised the project. All authors approved the final version of the manuscript. All authors read and approved the final manuscript

\section{Funding}

Open Access funding enabled and organized by Projekt DEAL. This study was supported by the Marie-Sklodowska-Curie Training Network"Immutrain" funded by the H2020 Program of the European Union (Grant 641549, KPH), the International Doctoral Program "i-Target"funded by the Elite Network of Bavaria (MS and KPH), the Collaborative Research Center 1243 "Cancer Evolution" of the Deutsche Forschungsgemeinschaft (IJ, MS and KPH), the Deutsche Forschungsgemeinschaft grants HO2489/10-1 and SU197/3-1 (KPH and MS), and the Exist Transfer of Research I grant (NCF).

\section{Availability of data and materials}

All data generated or analysed during this study are included in this published article [and its supplementary information files].

\section{Declarations}

\section{Ethics approval and consent to participate}

After obtaining written informed consent in accordance with the Declaration of Helsinki and approval by the Institutional Review Board of the LudwigMaximilians-Universität, peripheral blood, bone marrow or leukoreduction material was collected from AML patients and healthy donors. All animal studies were performed in accordance with the current ethical standards of the official committee on animal experimentation (written approval by Regierung von Oberbayern, ROB-55.2Vet-2532. Vet_02-16-7 and ROB-55.2Vet-2532. Vet_03-16-56).

\section{Consent for publication}

Not applicable.

\section{Competing interests}

KPH, MS and NCF are inventors of a patent application regarding the SIRPaantibody fusion proteins.

\section{Author details \\ ${ }^{1}$ Gene Center and Department of Biochemistry, Ludwig-Maximilians-Univer- sität München, Feodor-Lynen-Straße 25, 81377 Munich, Germany. ${ }^{2}$ Research Unit Apoptosis in Hematopoietic Stem Cells, Helmholtz Zentrum München, German Research Center for Environmental Health (HMGU), Neuherberg, Germany. ${ }^{3}$ German Cancer Consortium (DKTK), Partner Site Munich, Munich, Germany. ${ }^{4}$ Laboratory for Translational Cancer Immunology, Gene Center, LMU Munich, Munich, Germany. ${ }^{5}$ Department of Hematology and Oncol- ogy, Department of Medicine III, University Hospital, LMU Munich, Munich, Germany. ${ }^{6}$ Department of Transfusion Medicine, Cellular Therapeutics and Hemostaseology, University Hospital, LMU Munich, Munich, Germany. ${ }^{7}$ Department of Pediatrics, Dr. von Hauner Children's Hospital, LMU Munich, Munich, Germany.}

Received: 5 March 2021 Accepted: 7 September 2021

Published online: 27 September 2021

\section{References}

1. Shlush LI, Mitchell A, Heisler L, Abelson S, Ng SWK, Trotman-Grant A, et al. Tracing the origins of relapse in acute myeloid leukaemia to stem cells. Nature. 2017;547(7661):104-8.

2. Wulf GG, Wang RY, Kuehnle I, Weidner D, Marini F, Brenner MK, et al. A leukemic stem cell with intrinsic drug efflux capacity in acute myeloid leukemia. Blood. 2001;98(4):1166-73.
3. Dohner H, Estey E, Grimwade D, Amadori S, Appelbaum FR, Buchner T, et al. Diagnosis and management of AML in adults: 2017 ELN recommendations from an international expert panel. Blood. 2017;129(4):424-47.

4. Tsai RK, Discher DE. Inhibition of "self" engulfment through deactivation of myosin-II at the phagocytic synapse between human cells. J Cell Biol. 2008;180(5):989-1003.

5. Majeti R, Chao MP, Alizadeh AA, Pang WW, Jaiswal S, Gibbs KD Jr, et al. CD47 is an adverse prognostic factor and therapeutic antibody target on human acute myeloid leukemia stem cells. Cell. 2009;138(2):286-99.

6. Jaiswal S, Jamieson CH, Pang WW, Park CY, Chao MP, Majeti R, et al. CD47 is upregulated on circulating hematopoietic stem cells and leukemia cells to avoid phagocytosis. Cell. 2009;138(2):271-85.

7. Vyas P, Knapper S, Kelly R, Salim R, Lubowiecki M, Royston D, et al. Initial phase 1 results of the first-in-class anti-CD47 antibody Hu5F9-G4 in relapsed/refractory acute myeloid leukemia patients. European Hematology Association Annual Meeting, Stockholm. 2018: (Abstract PF232).

8. Chao MP, Takimoto CH, Feng DD, McKenna K, Gip P, Liu J, et al. Therapeutic targeting of the macrophage immune checkpoint CD47 in myeloid malignancies. Front Oncol. 2019;9:1380.

9. Ring NG, Herndler-Brandstetter D, Weiskopf K, Shan L, Volkmer JP, George BM, et al. Anti-SIRPalpha antibody immunotherapy enhances neutrophil and macrophage antitumor activity. Proc Natl Acad Sci U S A. 2017;114(49):E10578-85.

10. Chao MP, Alizadeh AA, Tang C, Myklebust JH, Varghese B, Gill S, et al. AntiCD47 antibody synergizes with rituximab to promote phagocytosis and eradicate non-Hodgkin lymphoma. Cell. 2010;142(5):699-713.

11. Weiskopf K, Jahchan NS, Schnorr PJ, Cristea S, Ring AM, Maute RL, et al. CD47-blocking immunotherapies stimulate macrophage-mediated destruction of small-cell lung cancer. J Clin Investig. 2016;126(7):2610-20.

12. Jain S, Van Scoyk A, Morgan EA, Matthews A, Stevenson K, Newton $\mathrm{G}$, et al. Targeted inhibition of CD47-SIRPalpha requires Fc-FcgammaR interactions to maximize activity in T-cell lymphomas. Blood. 2019;134(17):1430-40.

13. Sallman DA, Asch AS, Malki MMA, Lee DJ, Donnellan WB, Marcucci G, et al. The first-in-class anti-CD47 antibody magrolimab (5F9) in combination with azacitidine is effective in MDS and AML patients: ongoing phase $1 \mathrm{~b}$ results. Blood. 2019;134(Supplement_1):569 (Abstract).

14. Reinhold MI, Lindberg FP, Plas D, Reynolds S, Peters MG, Brown EJ. In vivo expression of alternatively spliced forms of integrin-associated protein (CD47). J Cell Sci. 1995;108:3419-25.

15. Oldenborg PA, Zheleznyak A, Fang YF, Lagenaur CF, Gresham HD, Lindberg FP. Role of CD47 as a marker of self on red blood cells. Science. 2000;288(5473):2051-4.

16. Piccione EC, Juarez S, Liu J, Tseng S, Ryan CE, Narayanan C, et al. A bispecific antibody targeting CD47 and CD20 selectively binds and eliminates dual antigen expressing lymphoma cells. MAbs. 2015;7(5):946-56.

17. Piccione EC, Juarez S, Tseng S, Liu J, Stafford M, Narayanan C, et al. SIRPalpha-antibody fusion proteins selectively bind and eliminate dual antigen-expressing tumor cells. Clin Cancer Res. 2016;22(20):5109-19.

18. Ponce LP, Fenn NC, Moritz N, Krupka C, Kozik JH, Lauber K, et al. SIRPalpha-antibody fusion proteins stimulate phagocytosis and promote elimination of acute myeloid leukemia cells. Oncotarget. 2017;8(7):11284-301.

19. Jordan CT, Upchurch D, Szilvassy SJ, Guzman ML, Howard DS, Pettigrew AL, et al. The interleukin-3 receptor alpha chain is a unique marker for human acute myelogenous leukemia stem cells. Leukemia. 2000;14(10):1777-84.

20. Taussig DC, Pearce DJ, Simpson C, Rohatiner AZ, Lister TA, Kelly G, et al. Hematopoietic stem cells express multiple myeloid markers: implications for the origin and targeted therapy of acute myeloid leukemia. Blood. 2005;106(13):4086-92.

21. Haubner S, Perna F, Kohnke T, Schmidt C, Berman S, Augsberger C, et al. Coexpression profile of leukemic stem cell markers for combinatorial targeted therapy in AML. Leukemia. 2019;33(1):64-74.

22. Yan B, Chen Q, Shimada K, Tang M, Li H, Gurumurthy A, et al. Histone deacetylase inhibitor targets CD123/CD47-positive cells and reverse chemoresistance phenotype in acute myeloid leukemia. Leukemia. 2019;33(4):931-44.

23. Broughton SE, Hercus TR, Nero TL, Dhagat U, Owczarek CM, Hardy MP, et al. Crystallization and preliminary X-ray diffraction analysis of the interleukin-3 alpha receptor bound to the Fab fragment of antibody CSL362. Acta Crystallogr F Struct Biol Commun. 2014;70(Pt 3):358-61. 
24. Liu J, Wang L, Zhao F, Tseng S, Narayanan C, Shura L, et al. Pre-Clinical Development of a Humanized Anti-CD47 Antibody with Anti-Cancer Therapeutic Potential. PLoS ONE. 2015;10(9):e0137345.

25. Petrova PS, Viller NN, Wong M, Pang X, Lin GH, Dodge K, et al. TTI-621 (SIRPalphaFc): A CD47-blocking innate immune checkpoint inhibitor with broad antitumor activity and minimal erythrocyte binding. Clin Cancer Res. 2017;23(4):1068-79.

26. Hatherley D, Lea SM, Johnson S, Barclay AN. Polymorphisms in the human inhibitory signal-regulatory protein alpha do not affect binding to its ligand CD47. J Biol Chem. 2014;289(14):10024-8.

27. Dufour A, Schneider F, Metzeler KH, Hoster E, Schneider S, Zellmeier E, et al. Acute myeloid leukemia with biallelic CEBPA gene mutations and normal karyotype represents a distinct genetic entity associated with a favorable clinical outcome. J Clin Oncol. 2010;28(4):570-7.

28. Benthaus T, Schneider F, Mellert G, Zellmeier E, Schneider S, Kakadia PM, et al. Rapid and sensitive screening for CEBPA mutations in acute myeloid leukaemia. Br J Haematol. 2008;143(2):230-9.

29. Büchner T, Hiddemann W, Wörmann B, Löffler H, Gassmann W, Haferlach T, et al. Double induction strategy for acute myeloid leukemia: the effect of high-dose cytarabine with mitoxantrone instead of standard-dose cytarabine with daunorubicin and 6-thioguanine: a randomized trial by the German AML Cooperative Group. Blood. 1999;93(12):4116-24.

30. Vinholt PJ, Nybo M, Nielsen CB, Hvas A-M. Light transmission aggregometry using pre-coated microtiter plates and a Victor X5 plate reader. PLoS ONE. 2017;12(10):e0185675.

31. Krupka C, Kufer P, Kischel R, Zugmaier G, Bögeholz J, Köhnke T, et al. CD33 target validation and sustained depletion of AML blasts in long-term cultures by the bispecific T-cell-engaging antibody AMG 330. Blood. 2014;123(3):356-65

32. Krupka C, Kufer P, Kischel R, Zugmaier G, Lichtenegger FS, Kohnke T, et al. Blockade of the PD-1/PD-L1 axis augments lysis of AML cells by the CD33/CD3 BiTE antibody construct AMG 330: reversing a T-cell-induced immune escape mechanism. Leukemia. 2016;30(2):484-91.

33. Vick B, Rothenberg M, Sandhofer N, Carlet M, Finkenzeller C, Krupka C, et al. An advanced preclinical mouse model for acute myeloid leukemia using patients' cells of various genetic subgroups and in vivo bioluminescence imaging. PLOS ONE. 2015;10(3):e0120925.

34. Ebinger S, Zeller C, Carlet M, Senft D, Bagnoli JW, Liu WH, et al. Plasticity in growth behavior of patients' acute myeloid leukemia stem cells growing in mice. Haematologica. 2020;32:939.

35. Hu Y, Smyth GK. ELDA: extreme limiting dilution analysis for comparing depleted and enriched populations in stem cell and other assays. J Immunol Methods. 2009;347(1-2):70-8.

36. Kwong LS, Brown MH, Barclay AN, Hatherley D. Signal-regulatory protein alpha from the NOD mouse binds human CD47 with an exceptionally high affinity_implications for engraftment of human cells. Immunology. 2014;143(1):61-7

37. Busfield SJ, Biondo M, Wong M, Ramshaw HS, Lee EM, Ghosh S, et al. Targeting of acute myeloid leukemia in vitro and in vivo with an anti-CD123 mAb engineered for optimal ADCC. Leukemia. 2014;28(11):2213-21.

38. Pietsch EC, Dong J, Cardoso R, Zhang X, Chin D, Hawkins R, et al. Antileukemic activity and tolerability of anti-human CD47 monoclonal antibodies. Blood Cancer J. 2017:7(2):e536.

39. Ansell SM, Maris M, Lesokhin AM, Chen R, Flinn IW, Sawas A, et al. Phase 1 study of the CD47 blocker TTI-621 in patients with relapsed or refractory hematologic malignancies. Clin Cancer Res. 2021;27:2190-9.

40. Bakema JE, van Egmond M. Fc receptor-dependent mechanisms of monoclonal antibody therapy of cancer. Curr Top Microbiol Immunol. 2014;382:373-92.

41. Lapidot T, Sirard C, Vormoor J, Murdoch B, Hoang T, Caceres-Cortes J, et al. A cell initiating human acute myeloid leukaemia after transplantation into SCID mice. Nature. 1994;367(6464):645-8.

42. Sarry JE, Murphy K, Perry R, Sanchez PV, Secreto A, Keefer C, et al. Human acute myelogenous leukemia stem cells are rare and heterogeneous when assayed in NOD/SCID/IL2Rgammac-deficient mice. J Clin Investig. 2011;121(1):384-95

43. Willingham SB, Volkmer JP, Gentles AJ, Sahoo D, Dalerba P, Mitra SS, et al. The CD47-signal regulatory protein alpha (SIRPa) interaction is a therapeutic target for human solid tumors. Proc Natl Acad Sci U S A. 2012;109(17):6662-7.
44. Logtenberg MEW, Scheeren FA, Schumacher TN. The CD47-SIRPalpha immune checkpoint. Immunity. 2020:52(5):742-52.

45. Brooke G, Holbrook JD, Brown MH, Barclay AN. Human lymphocytes interact directly with CD47 through a novel member of the signal regulatory protein (SIRP) family. J Immunol. 2004;173(4):2562-70.

46. Advani R, Bartlett N, Smith S, Roschewski M, Popplewell L, Flinn I, et al. The first in class anti CD47 antibody HU5FY G4 + rituximab induces durable responses in relapsed/refractory dlbcl and indolent lymphoma: interim phase 1B/2 results. Hematol Oncol. 2019:37:89-90.

47. Sallman DA, Asch AS, Kambhampati S, Al Malki MM, Zeidner JF, DonnelIan W, Lee DJ, Vyas P, Jeyakumar D, Mannis GN, Tanaka TN, Chai-Ho W, Larson RA, Whiteley AR, Marcucci G, Komrokji RS, Garcia-Manero G, Van Elk J, Lin M, Maute R, Volkmer J-P, Takimoto CH, Chao MP, Daver N. The first-in-class anti-CD47 antibody magrolimab combined with azacitidine is well-tolerated and effective in AML patients: phase $1 \mathrm{~b}$ results. Blood. 2020;21(Supplement_1):S213.

48. Zeidan AM, DeAngelo DJ, Palmer JM, Seet CS, Tallman MS, Wei X, et al. A phase I study of CC-90002, a monoclonal antibody targeting CD47, in patients with relapsed and/or refractory (R/R) acute myeloid leukemia (AML) and high-risk myelodysplastic syndromes (MDS): final results. Blood. 2019;134(1):1320

49. Qi J, Li J, Jiang B, Jiang B, Liu H, Cao X, et al. A phase I/lla study of lemzoparlimab, a monoclonal antibody targeting CD47, in patients with relapsed and/or refractory acute myeloid leukemia (AML) and myelodysplastic syndrome (MDS): initial phase I results. Blood. 2020;136(Supplement 1):30-1.

50. Weiskopf K, Ring AM, Ho CC, Volkmer JP, Levin AM, Volkmer AK, et al. Engineered SIRPalpha variants as immunotherapeutic adjuvants to anticancer antibodies. Science. 2013;341(6141):88-91.

51. Zhao XW, van Beek EM, Schornagel K, Van der Maaden H, Van Houdt M, Otten MA, et al. CD47-signal regulatory protein-alpha (SIRPalpha) interactions form a barrier for antibody-mediated tumor cell destruction. Proc Natl Acad Sci U S A. 2011;108(45):18342-7.

52. Advani R, Flinn I, Popplewell L, Forero A, Bartlett NL, Ghosh N, et al. CD47 blockade by Hu5F9-G4 and rituximab in non-Hodgkin's lymphoma. N Engl J Med. 2018;379(18):1711-21.

53. Ishikawa F, Yoshida S, Saito Y, Hijikata A, Kitamura H, Tanaka S, et al. Chemotherapy-resistant human AML stem cells home to and engraft within the bone-marrow endosteal region. Nat Biotechnol. 2007;25(11):1315-21.

54. Weinstein JN, van Osdol W. The macroscopic and microscopic pharmacology of monoclonal antibodies. Int J Immunopharmacol. 1992;14(3):457-63.

55. Godwin CD, Gale RP, Walter RB. Gemtuzumab ozogamicin in acute myeloid leukemia. Leukemia. 2017;31(9):1855-68.

56. Fournier E, Duployez N, Ducourneau B, Raffoux E, Turlure P, Caillot D, et al. Mutational profile and benefit of gemtuzumab ozogamicin in acute myeloid leukemia. Blood. 2020;135(8):542-6.

57. Fenwarth L, Fournier E, Cheok M, Boyer T, Gonzales F, Castaigne S, et al. Biomarkers of gemtuzumab ozogamicin response for acute myeloid leukemia treatment. Int J Mol Sci. 2020;21(16):5626.

58. Boyd-Kirkup J, Thakkar D, Brauer P, Zhou J, Chng W-J, Ingram PJ. HMBD004, a novel anti-CD47xCD33 bispecific antibody displays potent anti-tumor effects in pre-clinical models of AML. Blood. 2017:130(Supplement 1):1378.

59. van der Velden VHJ, te Marvelde JG, Hoogeveen PG, Bernstein ID, Houtsmuller AB, Berger MS, et al. Targeting of the CD33-calicheamicin immunoconjugate Mylotarg (CMA-676) in acute myeloid leukemia: in vivo and in vitro saturation and internalization by leukemic and normal myeloid cells. Blood. 2001;97(10):3197-204.

60. van der Jagt RHC, Badger CC, Appelbaum FR, Press OW, Matthews $D C$, Eary JF, et al. Localization of radiolabeled antimyeloid antibodies in a human acute leukemia xenograft tumor model. Can Res. 1992;52(1):89-94

61. Walter RB, Appelbaum FR, Estey EH, Bernstein ID. Acute myeloid leukemia stem cells and CD33-targeted immunotherapy. Blood. 2012;119(26):6198-208.

62. Vergez F, Green AS, Tamburini J, Sarry JE, Gaillard B, Cornillet-Lefebvre P, et al. High levels of CD34+CD38low/-CD123+ blasts are predictive of an adverse outcome in acute myeloid leukemia: a Groupe Ouest-Est des 
Leucemies Aigues et Maladies du Sang (GOELAMS) study. Haematologica. 2011;96(12):1792-8.

63. Vergez F, Nicolau-Travers ML, Bertoli S, Rieu JB, Tavitian S, Bories P, et al. CD34(+)CD38(-)CD123(+) leukemic stem cell frequency predicts outcome in older acute myeloid leukemia patients treated by intensive chemotherapy but not hypomethylating agents. Cancers (Basel). 2020;12(5):1174.

64. Perna F, Berman SH, Soni RK, Mansilla-Soto J, Eyquem J, Hamieh M, et al. Integrating proteomics and transcriptomics for systematic combinatorial chimeric antigen receptor therapy of AML. Cancer Cell. 2017;32(4):506-19. e5.

65. Testa U, Pelosi E, Castelli G. CD123 as a therapeutic target in the treatment of hematological malignancies. Cancers (Basel). 2019;11(9):1358.

66. Jen EY, Gao X, Li L, Zhuang L, Simpson NE, Aryal B, et al. FDA approval summary: tagraxofusp-erzs for treatment of blastic plasmacytoid dendritic cell neoplasm. Clin Cancer Res. 2020;26(3):532-6.

67. Uy GL, Aldoss I, Foster MC, Sayre PH, Wieduwilt MJ, Advani AS, et al. Flotetuzumab as salvage immunotherapy for refractory acute myeloid leukemia. Blood. 2020;137:751-62.

68. Smith BD, Roboz GJ, Walter RB, Altman JK, Ferguson A, Curcio TJ, et al. First-in man, phase 1 study of CSL362 (anti-IL3Ra/anti-CD123 monoclonal antibody) in patients with CD123+ acute myeloid leukemia (AML) in CR at high risk for early relapse. Blood. 2014;124(21):120

69. Epling-Burnette PK, Bai F, Painter JS, Rollison DE, Salih HR, Krusch M, et al. Reduced natural killer (NK) function associated with high-risk myelodysplastic syndrome (MDS) and reduced expression of activating NK receptors. Blood. 2007;109(11):4816-24.
70. Kubasch AS, Schulze F, Giagounidis A, Gotze KS, Kronke J, Sockel K, et al. Single agent talacotuzumab demonstrates limited efficacy but considerable toxicity in elderly high-risk MDS or AML patients failing hypomethylating agents. Leukemia. 2020;34(4):1182-6.

71. Montesinos P, Roboz GJ, Bulabois CE, Subklewe M, Platzbecker U, Ofran Y, et al. Safety and efficacy of talacotuzumab plus decitabine or decitabine alone in patients with acute myeloid leukemia not eligible for chemotherapy: results from a multicenter, randomized, phase 2/3 study. Leukemia. 2020;35:62-74.

72. Deuse T, Hu X, Agbor-Enoh S, Jang MK, Alawi M, Saygi C, et al. The SIRPaCD47 immune checkpoint in NK cells. J Exp Med. 2021. https://doi.org/ 10.1084/jem.20200839.

73. Tseng D, Volkmer JP, Willingham SB, Contreras-Trujillo H, Fathman JW, Fernhoff NB, et al. Anti-CD47 antibody-mediated phagocytosis of cancer by macrophages primes an effective antitumor T-cell response. Proc Natl Acad Sci U S A. 2013;110(27):11103-8.

74. Li Y, Zhang M, Wang X, Liu W, Wang H, Yang YG. Vaccination with CD47 deficient tumor cells elicits an antitumor immune response in mice. Nat Commun. 2020;1 1(1):581.

75. Liu X, Pu Y, Cron K, Deng L, Kline J, Frazier WA, et al. CD47 blockade triggers T cell-mediated destruction of immunogenic tumors. Nat Med. 2015;21(10):1209-15.

\section{Publisher's Note}

Springer Nature remains neutral with regard to jurisdictional claims in published maps and institutional affiliations.
Ready to submit your research? Choose BMC and benefit from:

- fast, convenient online submission

- thorough peer review by experienced researchers in your field

- rapid publication on acceptance

- support for research data, including large and complex data types

- gold Open Access which fosters wider collaboration and increased citations

- maximum visibility for your research: over $100 \mathrm{M}$ website views per year

At BMC, research is always in progress.

Learn more biomedcentral.com/submissions 